\title{
Anaerobic digestion and integration at urban scale: feedback and comparative case study
}

\author{
J. R. Bautista Angeli ${ }^{1,2^{*}}$ (D, A. Morales ${ }^{1}$, T. LeFloc' $h^{2}$, A. Lakel $^{2}$ and Y. Andres ${ }^{1}$
}

\begin{abstract}
Background: The anaerobic digestion process is well studied and developed since the last 50 years, notably for farming implementation. Furthermore, the international energy agenda has shifted in favor of renewable resources. In this context, anaerobic digestion has been highlighted as a valuable source of green energy. At urban scale, since the 2000s, some eco-friendly districts and cities tried to integrate this process as valorization treatment, with different approaches and results. The objective of this study is to provide a feedback from these anaerobic digestion projects at urban scale.
\end{abstract}

Methods: To construct this paper, 15 international projects of urban waste valorization were selected and studied. Three of these projects are developed to describe the different elements and processes implied in these valorization systems. Thus, in situ and ex situ anaerobic digestions are described with functional implementation and units in development or abandoned. Once the leading steps and main parameters on waste management system identified, the discussion is performed to compare the operational systems implemented in the 15 cases studies. The analysis takes processes and biological parameters into account in addition to social, financial, and ecological elements available. The achievements and limits of case studied linked to their context, bringing advice and recommendations.

Results: From these real cases and projects, we highlighted relevant information for further urban waste valorization system. Among others, the most frequent organic deposits produced at urban scale are identified, as well as the typical quantities generated. Collection, storage, and pretreatment processes were investigated to provide information about how they are conducted in situ and ex situ. Concerning some technical points, CSTR and UASB configurations are also identified as predominant reactors used to lead wet AD process at urban scale, due to practical aspects and characteristics of feedstock. Concerning the digestate, nutrients contents make it an interesting fertilizer for agricultural valorization. To its stabilization, the composting process is mainly deployed after anaerobic digestion of urban waste. The valorization of biogas produced with in situ urban AD is generally performed with CHP unit, due to the small quantity of methane. When the valorization is operated ex situ, processes are in link with local users' needs and energy transition policy.

(Continued on next page)

\footnotetext{
* Correspondence: jean.romain-bautista@cstb.fr

${ }^{1}$ IMT Atlantique, GEPEA (UMR CNRS 6144), 4 rue Alfred Kastler, 44307 Nantes,

France

${ }^{2}$ CSTB, Aquasim, 11 rue Henri Picherit, 44300 Nantes, France
}

(c) The Author(s). 2018 Open Access This article is distributed under the terms of the Creative Commons Attribution 4.0 International License (http://creativecommons.org/licenses/by/4.0/), which permits unrestricted use, distribution, and reproduction in any medium, provided you give appropriate credit to the original author(s) and the source, provide a link to the Creative Commons license, and indicate if changes were made. 


\begin{abstract}
(Continued from previous page)
Conclusion: In conclusion, we identified among others that available deposits, collection and storage processes, local grid, and scale mechanisms influence the urban integration of AD. Thus, anaerobic digestion in situ is emphasized for new district buildings with low urban density, while ex situ process could be more accommodated to high urban densities or projects including preexistent waste management. From the 15 case studies, co-digestion process is highlighted to perform global waste management and produce valuable AD reactions. Nevertheless, the use of blackwater, for in situ units, involves specific processes to limit amount of water and reduce the reactor sizing. Further knowledge is also currently needed about the development of collection systems for urban waste and the impact of pretreatment on AD. The involvement of scientific, economic, social, and political communities is also highlighted as essential for the long-term success of valorization system integrated at urban scale.
\end{abstract}

Keywords: Anaerobic digestion, Urban district, Sustainability model, Renewable energy

\section{Background}

The evolution of human societies now raises the question of the future of their energy and their environmental impacts [1]. With the depletion of fossil energy resources, we observe that international legislation and especially European policies lead to an energy transition focused on local and renewable resources. By 2050, it is estimated that the world population will reach 9.6 billion, $66 \%$ of whom will live in urban areas. Currently, $54 \%$ of the population live in these areas and cities already represent $70 \%$ of the total emissions of $\mathrm{CO}_{2}$ [2]. This defined the urban scale as target for the implantation of sustainable resources management [3]. Anaerobic digestion is one of the technologies highlighted for this transition due to its capacity to recover nutrients and carbon for soil fertilization, to valorize organic waste, and to produce energy such as biogas $[4,5]$. Indeed, the process may increase the fraction of renewable energy in the mix of a country's consumption. Moreover, with the amount of organic wastes in urban scale, this will lead to a renewable treatment of organic matter. At international level, some sustainable districts lead pilots on this way, supported by preexisting valorization process or take place in specific new unit. Although the potential is high, there is still a lack of knowledge to fit this process into tomorrow's urban areas [6].

As a model of new construction or rehabilitation, eco-districts are a response to reflection related to urbanism, environment, and sustainability [7]. The dwellings must support a sustainable management of resources, including innovative solutions, and also bring social and economic dynamism [8-11]. The eco-neighborhoods often range from 400 to 7000 inhabitants. They are compact in order to limit the distances between the inhabitants and the economic and cultural interests. The absence or limitation in the use of automobiles reinforces proximity synergies and leads to the reduction of greenhouse gases [12]. The dwellings are staggered (2-3 floors), and the density is studied to respect concepts of "threshold of viability," which are favorable to social ties [13]. The uninhabited spaces are generally transformed into urban gardens, close to the housing [14]. The development of a sustainable neighborhood involves the creation of schools, canteens, stores, and the establishment of a local and economic network. These aspects are especially important in the success of the circular economy model. In point of fact, social proximity naturally encourages and rewards good initiatives while diminishing individualistic behaviors [15]. The inhabitants of the eco-neighborhoods are generally more aware of the preservation of resources and the established social fabric boosts the emergence of citizen/ community actions [16]. Indeed, sustainable resources and energy management are at the heart of the design of an eco-neighborhood [17]. The reduction of consumption and the reuse of resources here are closely examined. In 2015, Pan and his team [18] identified four main barriers to the implementation of a waste-to-energy system (WTE): the economic, social, technological, and political aspects.

Current studies of urban anaerobic digestion provide scientific literature about urban waste digestion, pretreatment, and post-treatment at laboratory scale or pilot scale with national context. Nevertheless, technical data on real projects and follow-up on their functioning are less investigated. Studies about the understanding of influences from social or economic and political contexts on the processes deployed are also currently limited.

The purpose of this paper is to provide a reflection of anaerobic digestion process at urban scale via feedback on waste valorization systems. To this end, achievements and limits from urban projects, in situ and ex situ, are described, studied, and compared. The study is focused on the technological analysis of processes involved in anaerobic digestion at urban scale and supported by economic, social, and political elements.

\section{Methods}

To carry out this study, firstly, data was collected regarding scientific publications concerning anaerobic digestion at urban scale. Secondly, to increase the number of 
cases, we studied technical documents and reports about current and forthcoming urban anaerobic digestion projects. Many of the stakeholders were contacted to improve understanding about the development of wasteto-energy systems. A third investigation was carried out on sustainable districts or initiatives which did not include anaerobic digestion to understand the basis upon which the decision was made. However, the data collected was not comprehensive and was limited by difficulties in collecting information from local projects or by the restricted number of scientifically useable values. The contacts were research centers, architectural offices, private companies, and municipalities. Most references for these projects are presented in Tables 1 and 2.

For the construction of Tables 1 and 2, the 15 projects are grouped according to their location and the process used. Table 1 summarizes the information relating to the districts or city studied and the context of the integration. To screen the results collected, the following terminology was used. "Process in situ" corresponds to a valorization unit, with collection system, located within the area of the project. "Process ex situ" refers to a valorization unit located outside the area of the project and using the area's waste after transport. The number of lodgings is provided to contextualize the scale of these projects. However, this is not linked to the valorization structure, especially for AD ex situ, which can be supplied by other deposits than from the studied project. Elements of contexts and limits already available are also indicated. The status section refers to the development stage of valorization unit in each project, namely, developing, operating, or abandoned. The projects' starting date is included to relate the project and the technology implemented to its social, economic, and political context. Table 2 centralizes the elements available about the operational conditions applied in the valorization units. Even if the information is partial, the entire wastes management systems are considered to portray the processes and their specific utilizations. The mention of "urban/ district area extended" refers to a collection area wider than the one considered for the project case. It is the opposite for the mention of "area restricted."

From Tables 1 and 2, three cases were selected and developed. This selection consisted of choosing the most comprehensively studied and documented projects, for which data available provide a systemic approach of anaerobic digestion and its context. International publications from scientific sources were preferred. Moreover, a diversity of projects was selected with AD in situ and ex situ and the three different stages of development. Lastly, it was decided to consider only European districts developed from 2000 to remain within a common social, economic, and political context. The paragraphs are constructed to describe the entire system of anaerobic digestion integrated in these projects, with collection, storage, transport, pretreatment, and post-treatment. Schematic figures are presented in Figs. 1, 2, and 3 to summarize these models. Details on the infrastructures and equipment are also provided. These results describe anaerobic digestion management at urban scale in highlighting processes inherent to the valorization system.

Table 3 is constructed from publications and reports on the different cases studied and supported by reviews for comparative standard data. All the waste deposits used for valorization treatments studied are collated and details in terms of location, collection points, quantity, and physical-chemical analysis. Data concerning the collection take the source of deposit and the number of collection points into account. When data are available, mean values and standard deviation are provided; otherwise, minimum and maximum values are informed. Due to the variety of references used and the different nature of waste, units employed were not always homogeneous and had to be estimated.

The limits of this paper are principally related to the developing state of the case studies. Indeed, currently, the scientific literature and studies from anaerobic digestion in real urban projects are modest in number. Moreover, a fraction of these data is, provided by local reports, written in different languages, with a technical focus. Consequently, the information is partial, difficult to obtain, and does not always respond to fundamental scientific questions. For example, figures concerning the treatments yield or energetic costs and energy recovery are often only slightly investigated. Similarly, operational conditions used for monitored $\mathrm{AD}$ are frequently not fully detailed, which in addition to the various missing data limits the understanding of the global context and the performance of the analysis. Moreover, we assumed that the list of investigated projects is not exhaustive. Consequently, the chosen projects and their geographical position (majority EU) limit the analysis; indeed, each country has its own culture, life style, dietary habits, and organic wastes. These variables highly influence the management of the AD process and the social, political, or economic impacts, which have to be related to these elements. Nevertheless, this paper enables to identify information and advice for AD at urban scale, collected by comparing in situ and ex situ management of urban valorization treatment.

\section{Results}

Tables 1 and 2 present the 15 projects investigated. They are sorted according to their location and kind of process used. References also included the projects contacted during this study, marked by an asterisk.

The further section describes three projects selected from Tables 1 and 2. Paragraphs are focused on the 


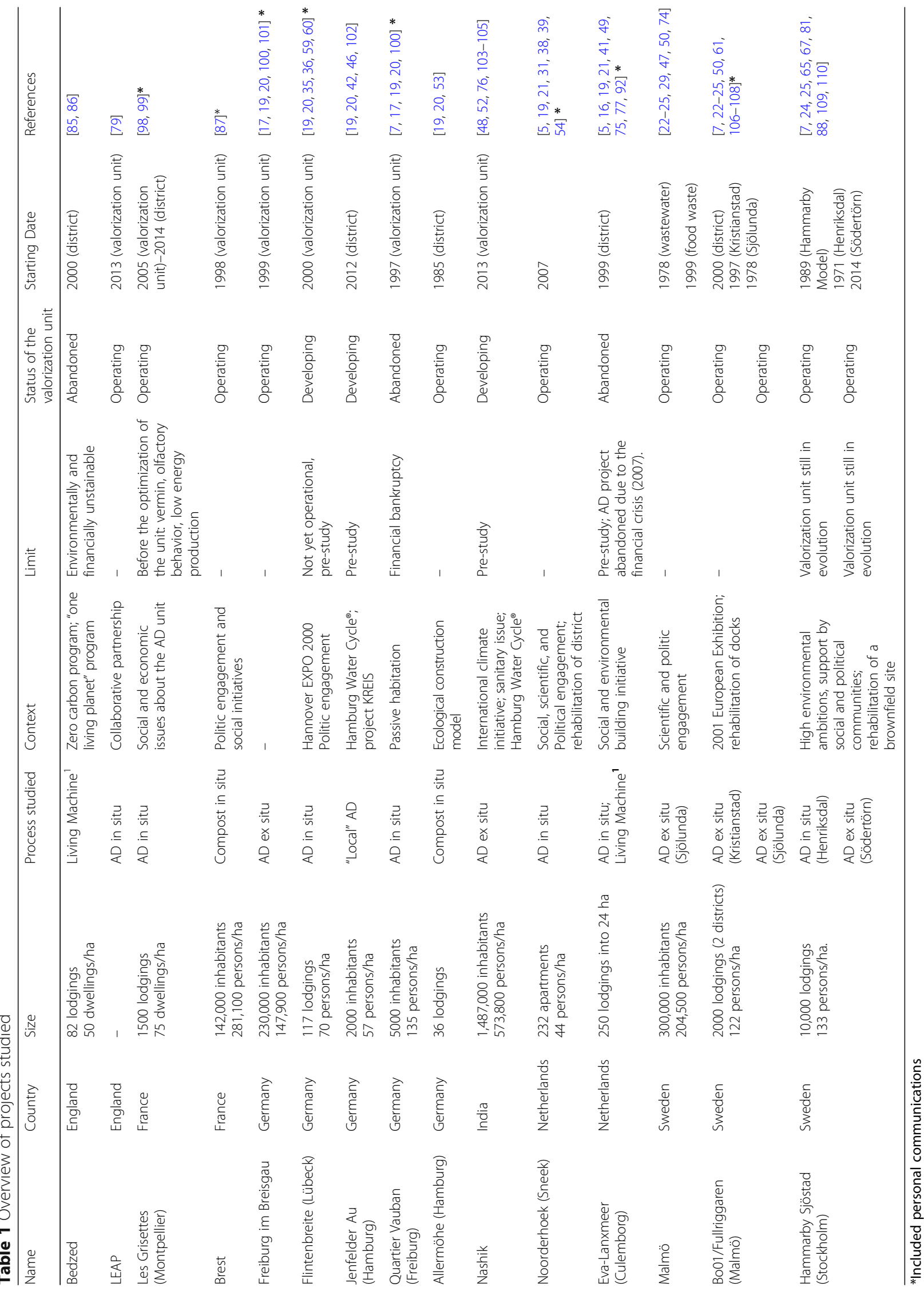




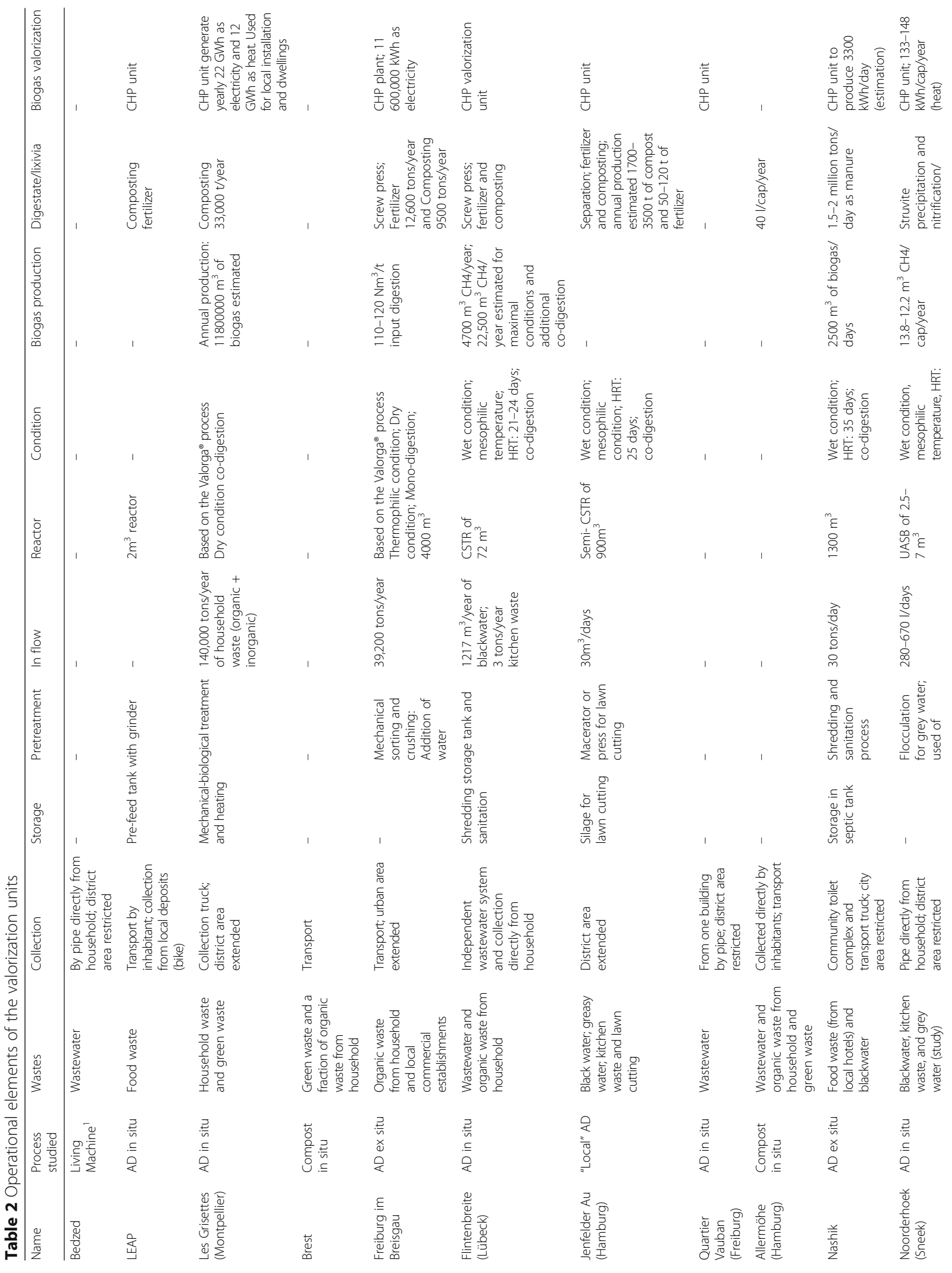




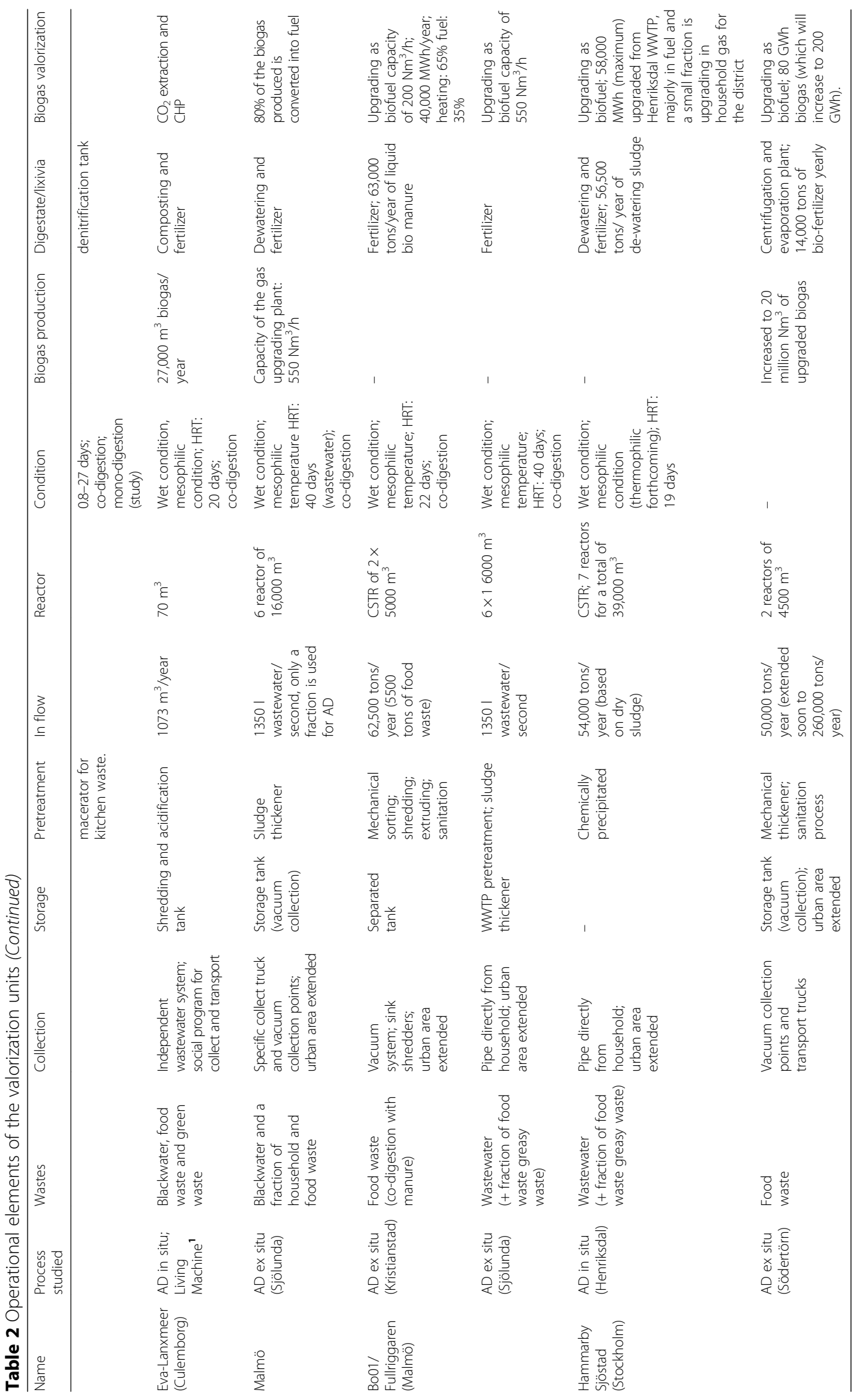




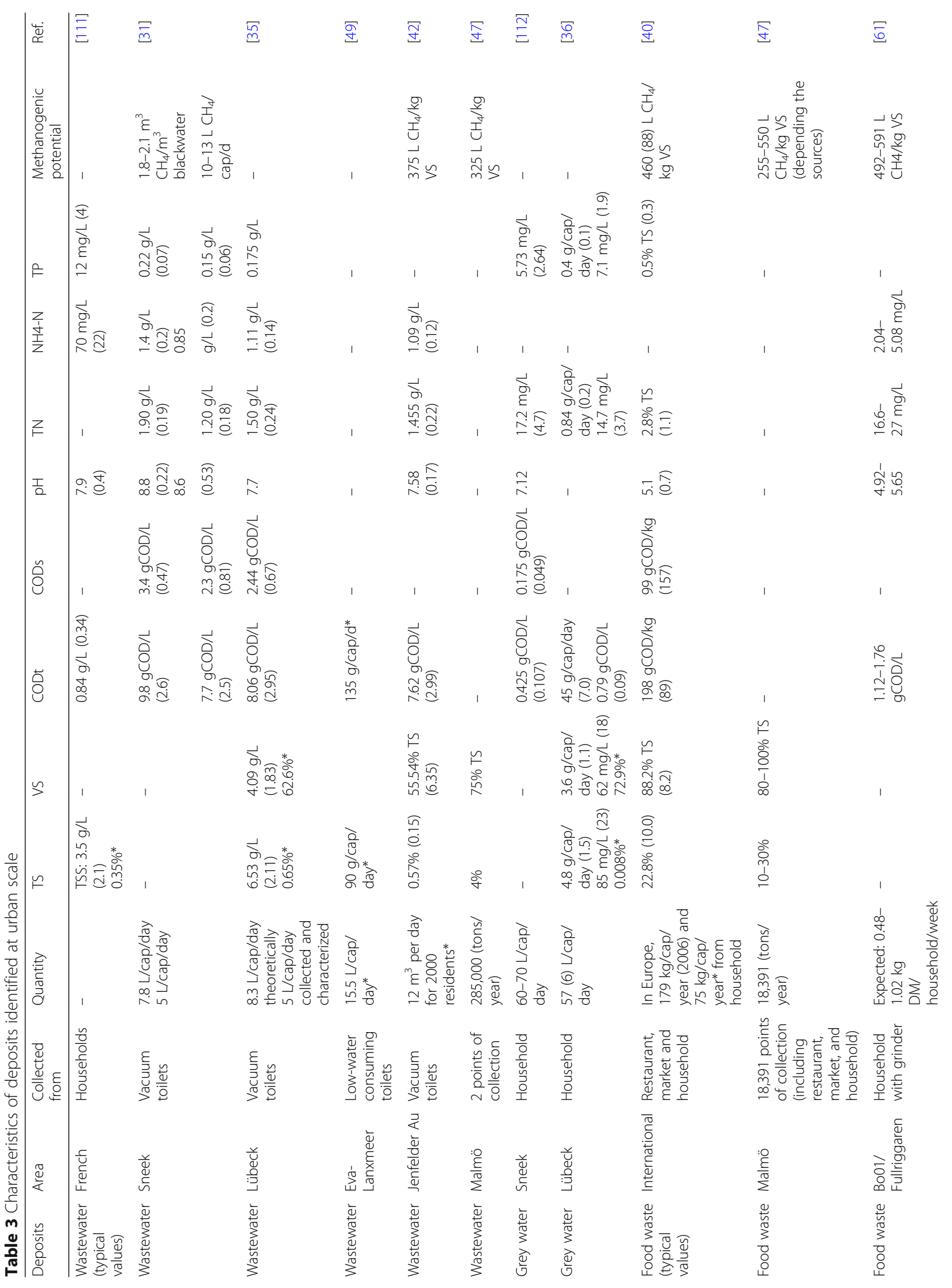




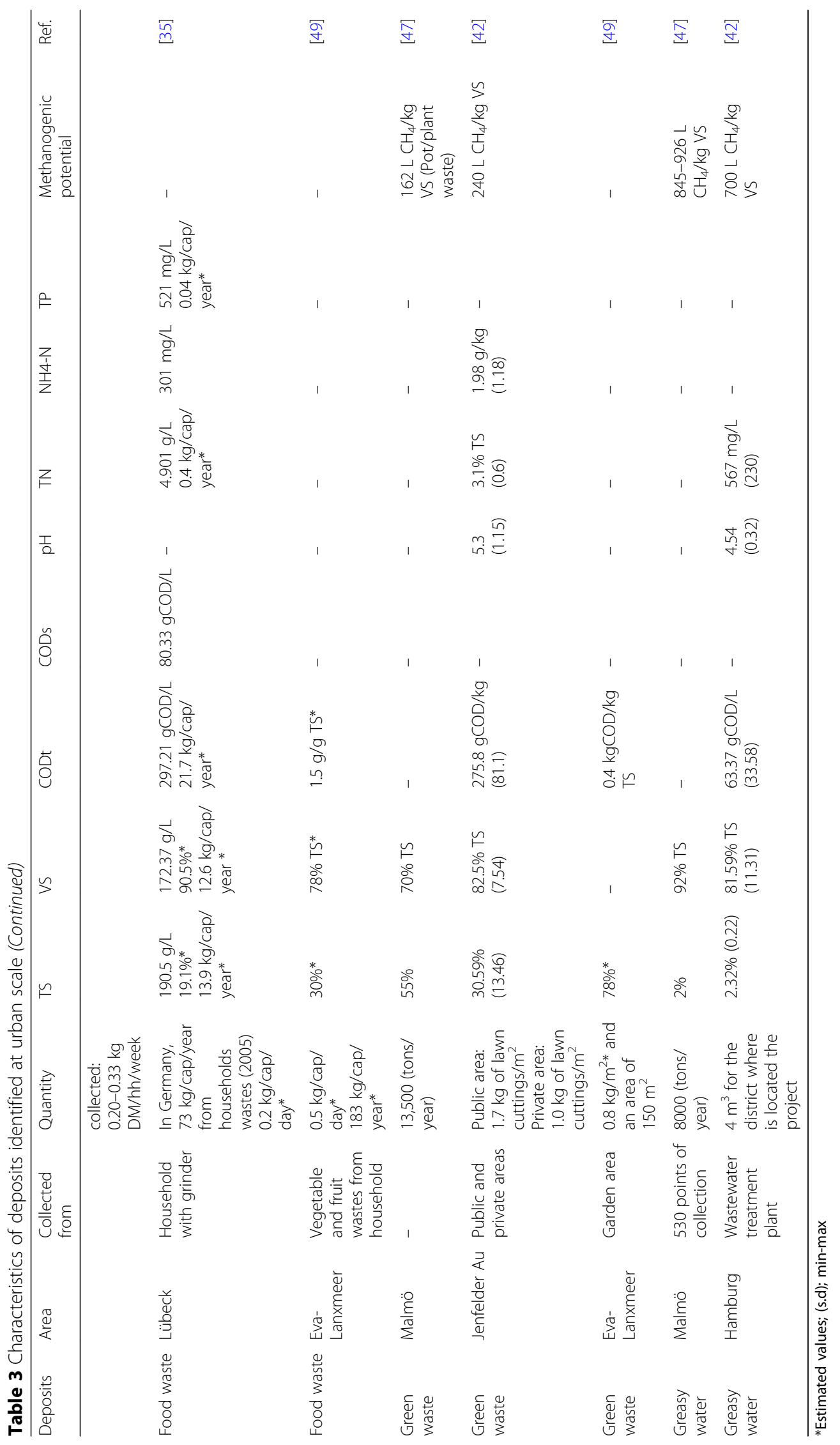


anaerobic digestion system and included interaction between upstream and downstream processes and specific context. For each one, a schematic view of the WTE system is performed to highlight the flow of organic waste. This is represented in Figs. 1, 2, and 3.

\section{Project 1: Flintenbreite}

This ecological housing is to be a part of a global project of the Hannover EXPO 2000. It is situated in the west of Lübeck and covers an area of 5.6 ha, of which 2.1 ha are left as natural green space. It consists of 117 accommodation units for up to 380 inhabitants. It is planned as a nearly car-free settlement with a central parking area. The housing is based on a circular ecological concept, which includes architecture, landscape planning, social cooperation, and energy and sanitation management. Grey water is transported by gravity pipes to several constructed wetlands. Rainwater from roofs and sealed areas is to be collected in small gutters and infiltrated to the groundwater in decentralized swales. The households will not be connected to the public wastewater network system of the city. Instead, the wastewater is to be collected and treated in an internal cycle. The habitations are to be equipped with vacuum toilets with very low water consumption. The blackwater (feces and urine) will be transported via a vacuum sewerage system to a storage tank.

At the end of 2015, in Flintenbreite, the anaerobic digestion process was still in development. The project corresponds to an in situ AD process, inserted in the heart of the eco-district. Preliminary studies reveal that blackwater, from the vacuum toilets, is up to three times more concentrated than the average recorded in Germany. The wastewater is then mixed with food waste recovered from homes by sink crushers. The amount of water is reduced to minimize the size of the reactor, and the shredded food waste is more easily degraded by microorganisms. In the project, a thermal pretreatment is to be carried out for sanitation purposes, in conformity with the country's regulations and also to reduce the digestion time [19]. Pretreatments are planned in tanks such as storage "bins" to avoid sudden influx into the different sections. The treated waste is easily degradable, and its flow is fractionated to be more convenient for the reactor. Regarding the reactor, a continuously stirred tank reactor (CSTR) was preferred. It was designed to run in wet process and mesophilic temperature conditions. The process is simple and well known; it does not require special maintenance or specific control of the TS, allowing the introduction of food waste. In preliminary studies, the utilization of the digestate is directly used as a fertilizer in agriculture. Biogas had to be used for cogeneration, thus producing heat and electricity. Given the quantity of waste treated and the size of the neighborhood, this kind of valorization seems the most suitable way to limit the losses and the financial investment that require post-treatment. Moreover, the proximity between the installation and the dwellings allows for a maximum return of the energy produced. The German Renewable Energy Act (EEG), since 2004, provides a budget allocation to support electricity and heat valorization projects $[19,20]$.

All the operations carried out around the anaerobic digestion unit are focused on reducing the size of the reactor. The insertion of the process considering its surrounding environment is crucial. The waste treatment network is closed and nuisance is limited thanks to the hermetic storage tank. Management system requires a minimal level of awareness, regarding the use of toilets and food waste collection. The involvement of the inhabitants in the process is intended to be minimal, which may be unfortunate considering the opportunity this allows at this implementation scale. The closed circuits proposed in this case provide much information. Nevertheless, this implementation is limited to "residences' dormitories." Indeed, it does not currently consider the collection of other organic waste (restaurant, local grocers...), which seems to

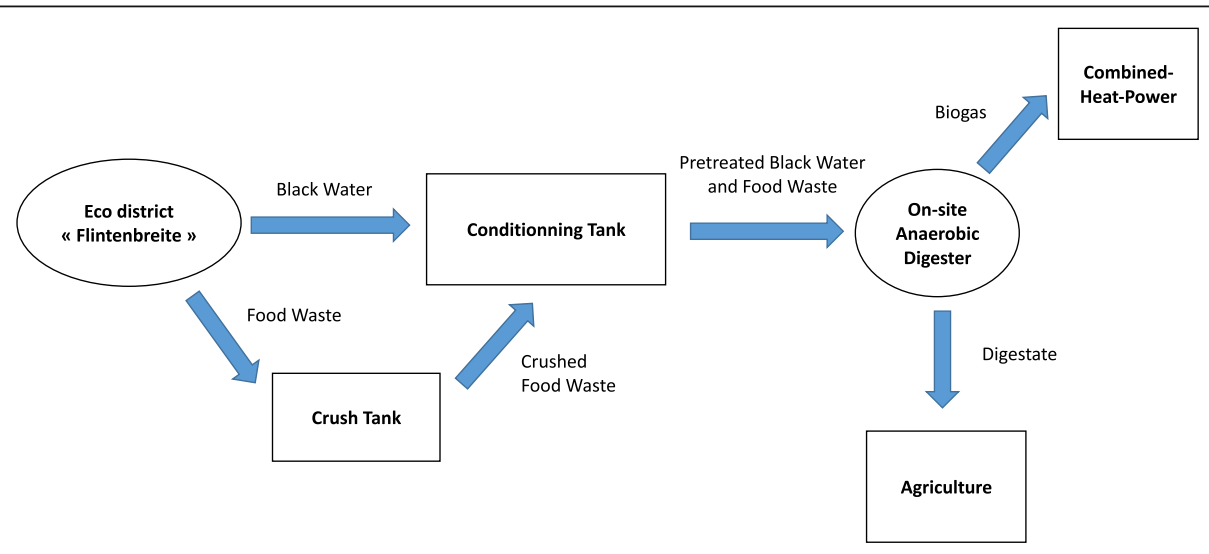

Fig. 1 Diagram of the WTE system on Flintenbreite 
limit the development to a neighborhood scale with low population and infrastructure. The creation of a closed circuit connecting all the residences is still not performed, which explain, in addition to the change of investors during the project, the fact that, currently, the anaerobic digestion process in Flintenbreite is not operational.

\section{Project 2: Eva-Lanxmeer}

Eva-Lanxmeer is a social-ecological district of 24 ha that has been built with sustainable materials on former farmland surrounding a protected drinking water extraction area. Located near the Culemborg railway station, the Lanxmeer project consists of 250 homes of which $13 \%$ are apartments, approx. $38 \%$ are subsidized rented and owner-occupied housing, $24 \%$ are middle-range owner-occupied housing, and $38 \%$ are luxury owner-occupied housing, collective permaculture gardens, business premises $\left(40,000 \mathrm{~m}^{2}\right.$ gross floor space) and offices $\left(27,000 \mathrm{~m}^{2}\right)$. In addition to a biological city farm $\left(48,000 \mathrm{~m}^{2}\right)$, the accommodation is completed by the EVA Centre (an education, information, and conference center), a hotel and a "Sustainable Implant" facility. However, the village was constructed but the EVA center and anaerobic digestion project have never been implemented due to the financial crisis in 2007. Nowadays, an "intentional community" is still the main foundation of social life in the district and is represented by inhabitants who take an active part in the eco-village.

Although it was abandoned, the environmental project remains a model for Decentralized Sanitation and Reuse (DESAR) concept integrated at the district scale. It includes a closed water circuit, with low-water consuming toilets and water management system, independent from the Culemborg city. It also contains an in situ small-scale biogas installation for the treatment of blackwater and organic waste/garden and park biomass, associated to a combined heat power (CHP) unit. The complete $\mathrm{AD}$ management solution is supported by a closed greenhouse, a Living Machine, ${ }^{1}$ sludge composting with organic food production, and further recycling through Retourette $^{2}$ with the possibility for joint e-commerce supply. The whole process is designed to create cycles for renewable resources.

The Eva-Lanxmeer project proposes, in one building, an autarkic recovery circuit centered on an anaerobic digestion process and connected to other processes such as the Living Machine ${ }^{1}$ and composting. It was also studied to limit energy losses and emphasize biogas production. As a part of the project, sedimentation of black water and shredding of green waste are carried out; then, this waste is mixed in a storage tank with food waste from dwellings. After this step, conventional pretreatments such as thermal or ultrasonic treatments are replaced by increased $\mathrm{pH}$. "Pre-acidification" is planned on the mix of waste at a temperature close to $25{ }^{\circ} \mathrm{C}$, in order to increase the production of VFA ( $\mathrm{pH}$ less than 6). This alternative, less costly in terms of energy, also pre-degrades the substrates, in particular ligno-cellulose in green waste, and increases the availability of the feedstock, at the same time. The goal of co-digestion is twofold: it increases the ratio of organic matter in the incoming flow and ensures a good production of biogas. In this case, it is also a good way to construct a closed valorization circuit which includes all the organic waste produced by the village and stay independent from the Culemborg city network. The anaerobic digestion process is planned in a wet and fully automated way. The minimum size of the reactor is estimated at $70 \mathrm{~m}^{3}$ for a HRT of 20 days. The operating temperature is mesophilic, close to $30{ }^{\circ} \mathrm{C}$. Afterwards, post-treatments or Living Machine are designed to recover heat and nutrient from the leachate produced and ensure a quality

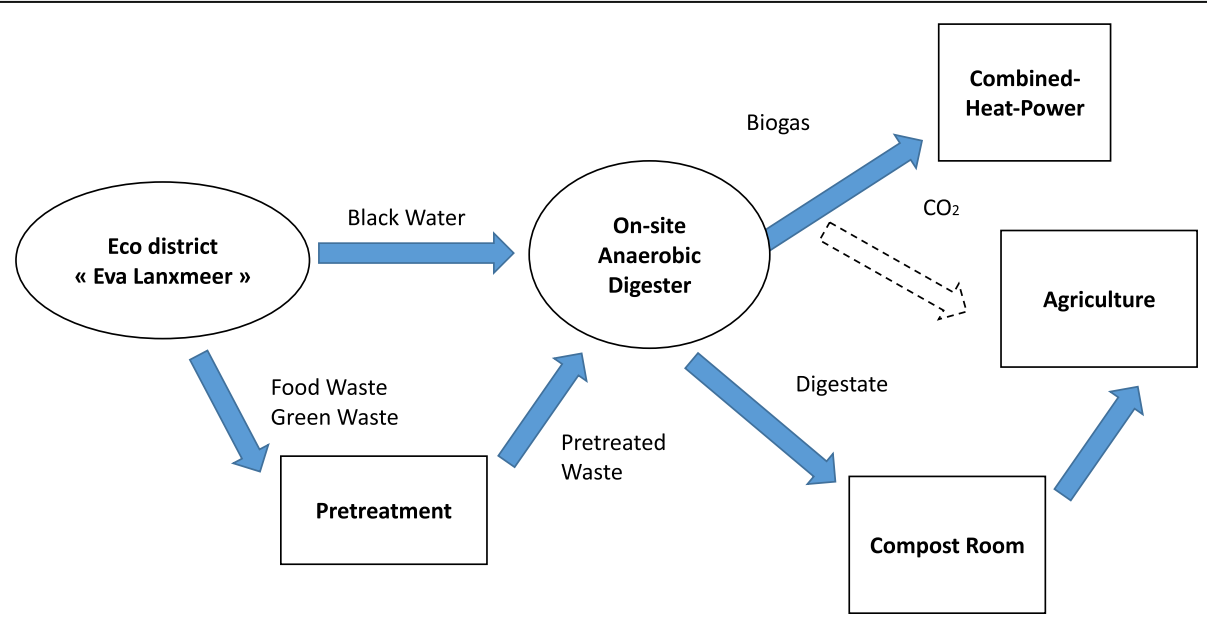

Fig. 2 Diagram of the WTE system on Eva-Lanxmeer 
profile to agricultural irrigation. The digestate is also beneficial for agriculture; after composting, it will be recovered as fertilizer. Finally, biogas had to be purified and stored to produce energy by CHP. The $\mathrm{CO}_{2}$ fraction extracted is planned to be used as a natural fossil gas equivalent, for agrarian greenhouses. Thus, the entire valorization circuit is designed to maximize energy and nutrient recovery. Indeed, national energy law includes a feed-in subsidy for biogas in CHP valorization plus a bonus if the heat produced is used effectively. The support from the government is based on a green deals approach $[5,19,21]$. However, the pre-study of the eco-district concludes that without an increase in the frequency of collection of green and food waste, biogas production would be too low to be economically attractive.

It is also important to note that the system presented in Eva-Lanxmeer is not the optimal option which was first conceived. This consisted of a vacuum system connected to the housing for direct collection of organic and blackwater waste prior to treatment.

The social aspect is crucial in the development of the Eva-Lanxmeer project. Initially, the inhabitants are involved in the anaerobic digestion process through the collection step, which depends on the sorting and the transportation of food waste (FW) and green waste $(\mathrm{GW})$ by farmers. Indeed, nearby storage premises (Retourette ${ }^{2}$ ) are used as "bins," and frequent transport of the waste to the anaerobic digester has to be performed by local farmers. Even if the complete system seems to be difficult to implement in other cases, it adds an interesting social aspect to the valorization process with the involvement of inhabitants. First, sensitization was also discussed to change the behavior of the residents, for instance, preventing the use of biocidal products for cleaning toilets which are directly connected to the digester. Ultimately, the question of the feasibility of such an experiment still remains. Eva-Lanxmeer has a unique social framework but has many economic and political repercussions which led finally to the abandonment of the anaerobic digestion process. Despite its limitations, the project is nevertheless well documented and examined, since it has served as a model for the construction of many other eco-districts. In addition, it is the first project to design anaerobic digestion at the scale of an ecological village. Here, urban and rural environments (farms) are called upon to operate the process. Moreover, anaerobic digestion is a co-digestion in order to enhance a set of organic waste and it is not offered as a single solution but will be linked with other recovery processes in order to obtain a quasi-autarky system.

\section{Project 3: Bo01/Fullriggaren}

The third and last case is located in the Western Harbor of Malmö with a specific focus on the Bo01 and Fullriggaren districts. The global project consisted of the transformation of former ports into sustainable neighborhoods. The operation was contemplated in the framework of the "2001 European Exhibition," an exhibition dedicated to the construction of cities of the future. In the Western Harbor, a new technical approach for waste management and local renewable sources was implemented and studied.

The initial characteristics of the Bo01 project include 1303 dwellings on 22 ha over an old industrial port area. The density of buildings is 600 units for 9 ha (first floor) and the population density is 122 persons/ha. The overall project comprises commercial, administrative, social, educational, cultural, and recreational areas. The Bo01

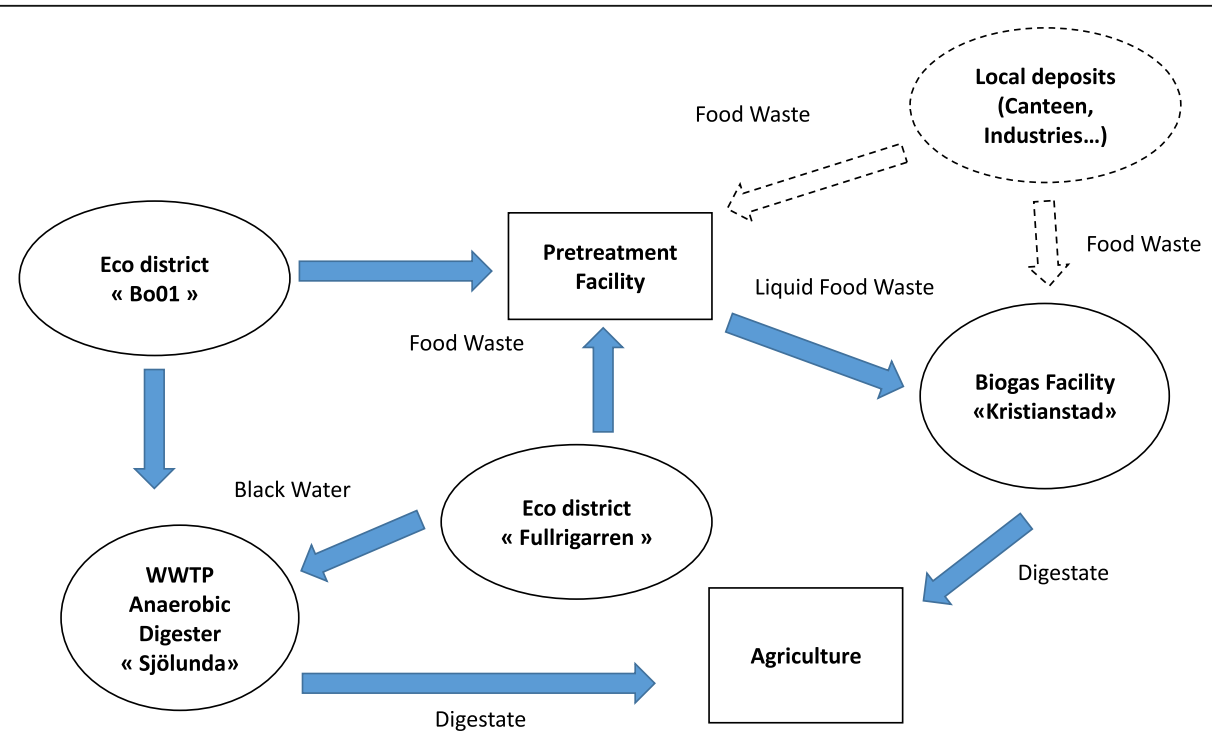

Fig. 3 Diagram of the WTE system on Bo01-Fullriggaren 
housing is connected to the public wastewater system of the city and the wastewater treatment plant (WWTP) of Sjölunda. Regarding food waste, a first study was made with 41 apartments on the different ways to collect food waste in the district. One way was to equip households with a kitchen grinder; another option corresponds to the use of paper bags for collection in several outdoor collection points equipped with a vacuum system. After collection, food waste is transported to a pretreatment plant outside the district by vacuum suction vehicles and then to Kristianstad biogas plant.

The Fullriggaren district has 614 apartments spread over 16 properties; it is located near the preceding district and was created based on feedback from Bo01. When the area was built, in 2012, the process of food waste separation was adapted from the results of Bo01's study on waste quality, social opinion, and the limitations of pretreatment processes. Consequently, sink shredders are implemented in all apartments and directly connected to a storage network. Indeed, the houses are built with double drain strains; the first one connected to the toilet goes to the WWTP of Sjölunda. There, the organic fraction is used in the anaerobic digester of the WWTP. The second strains, from the grinders, lead food waste and kitchen wastewater to a separation tank. After storage in the tank, the water fraction is reconnected to the Sjölunda WWTP flow [22]. The food waste part is concentrated sludge, and although the grid would be able to transport this to the WWTP, the pretreatment of waste would be more difficult and expensive to carry out. Consequently, the operational management is, as in Bo01, the transport of food waste from the storage tank to an external pretreatment unit (SYSAV) [23]. There, the FW of the district and that coming from the local deposits (restaurants, canteens, industries) are mixed. The non-degradable elements are extracted, and the mix is diluted by the timely addition of liquid FW like sauce or juice, or the addition of water. Due to the threshold capacity of the anaerobic plant in the WWTP station in Sjölunda, food waste is centralized outside the district, in another valorization unit, at Kristianstad's biogas plant. The upgrading of biogas at Kristianstad produces heat and electricity from food waste mix with local industrial and agricultural wastes, but consequently, the energy produced is not beneficial to the districts studied. However, most of the biogas valorization is done by upgrading it into vehicle fuel which has been well established in Sweden and is relevant considering the volumes of biogas generated. National incentives also promote gas vehicles, gas stations, or development in terms of biogas technology, by grant mechanism or competitive tax advantage $[24,25]$. The digestate produced is used as fertilizer in agriculture. Anaerobic digestion processes, designed for Bo01 and
Fullriggaren, have the merit of still being in operation and offer valuable feedback for management of ex situ AD.

Table 3 summarizes the physical-chemical characteristics of the main deposits identified in case studies. Values are provided by project literatures. Typical values from reviews are also included as comparative data.

\section{Discussion}

Tables 1, 2, and 3 regrouped a large quantity of elements which composed a fragmented data of urban AD management. Based on the scientific literature and technical information available from projects 1,2 , and 3 , their description enables to identify the main variables driving these systems. Indeed, these results display the multitude of processes involved in urban anaerobic digestion. They also highlighted the interactions with existing social, economic, and politic contexts. Through this, the discussion is based on the crucial steps and main parameters identified as leading urban waste management. The comparison is realized on data from the three developed cases and also includes all the partial information collected in Tables 1, 2, and 3.

\section{Waste selection}

To develop an anaerobic digestion process to treat organic waste, it is necessary to consider (i) the quantity available, the seasonality, and current waste management already realized; (ii) the collection points; (iii) the physical-chemical characterization; (vi) and the methanogenic potential.

As indicated in Table 3, generally, the chemical organic demand (COD), TS, and VS percentage are the main determinates of physical-chemical parameters. A stable feedstock is usually characterized by $\mathrm{COD} / \mathrm{N} / \mathrm{P}$ or $\mathrm{C} / \mathrm{N} / \mathrm{P}$ ratios. $\mathrm{C} / \mathrm{N}$ typical ratio for the feed stream is around 20-30 [26-28]. Some studies also investigated the biodegradability and the chemical profile of waste. Indeed, the lignin content drastically reduces waste biodegradability. Sulphur and nitrogen fraction and their different chemical compounds are dosed to ensure a high production of methane and guard against inhibitions $[29,30]$. The biochemical methane potential is also often measured during study stages.

The principal wastes found to be used for anaerobic digestion in urban areas are:

- Wastewater. It is used in a majority of anaerobic digestion case studies. It corresponds to the water produced from use of toilets and sometimes in addition of kitchens too. Its composition depends on the collection system and treatment used [31]. Blackwater (brown if urine-free) is obtained by separating toilet water and includes the major part 
of organic material in domestic wastewater, with a significant amount of nutrients $(\mathrm{N}$ and $\mathrm{P})$ and pathogens. The waste is defined (Table 3) by a significant available deposit, with low TS between 0.5 and $4 \%$ and a VS between 55 and $75 \%$ TS, depending on how diluted in urine it is [32-35]. Wastewater can also be composed of a significant amount of toilet paper. The waste is interesting due to its important daily supply and high concentration in VS; it produces near to $350 \mathrm{~L} \mathrm{CH}_{4} / \mathrm{kg} \mathrm{VS}$. At district scale, the use of vacuum toilets provides between 5 and $15.5 \mathrm{~L} / \mathrm{cap} /$ day of waste depending on the efficiency of water separation. WWTP produced different kind of sludges from this deposit [27]. Primary sludges are the most concentrated in terms of TS and VS. Chemically, the composition is quite similar to wastewater unless a chemical pretreatment is carried out [33].

- Grey water. The composition of greywater is highly impacted by the surrounding context. It is generally admitted that the waste represents about 70\% volume fraction of domestic wastewater, which corresponds to a volume comprised between 57 and 70 L/cap/day. Despite its abundance, it compounds of a considerable amount of phosphorus due to detergent and dishwashing powder [36, 37]. The organic load is also very low, with a TS $<0.01 \%$ and a VS of $75 \%$ TS, but sufficient to perform anaerobic digestion under specific conditions in terms of HRT or pretreatment [38]. Nevertheless, investigations about Sneek pilot (Tables 1 and 2) reveal that aerobic digestion removes $80 \%$ of COD, when only $42 \%$ of COD is treated when AD is used in the conditions of their study [39].

- Food waste. The quantity and composition of food waste are variable depending on cultural and seasonal parameters or economic area location. Fisgativa et al. [40] define average food waste as a TS of $22 \% \pm 10.0$ and a VS of $88.2 \% \pm 8.2$, which demonstrated a good profile for biogas production by anaerobic digestion. This production depends on the wastes sources, but nevertheless, 469.6 $\mathrm{L} \mathrm{CH}_{4} / \mathrm{kg}$ VS on average are obtained during studies. The deposit can be provided by restaurants, canteens, households, or wholesalers (fruit and vegetables). Consequently, it may include paper towels, packaging, paper bags, or certain contaminants (metal, plastic...). Moreover, a higher collection of food waste was observed in rural areas than in large cities, up to five times [41]. It admitted that close to $0.2 \mathrm{~kg} / \mathrm{cap} /$ day could be collected from households and $0.5-1 \mathrm{~kg} / \mathrm{cap} /$ day with the additional collection from restaurants and markets (Table 3 ).
- Green waste. Commonly, garden waste presents around $31-78 \%$ of total solids and $70-83 \%$ of VS out of the TS. However, the lignin fraction in the VS fraction can be high if a substantial part of bulky garden waste is collected (wood from pruning). This latter fraction is much more suitable for pyrolysis treatment or composting on site [42-45]. Conversely, fresh lawn cuttings are humid and contain high shares of easily fermentable organic compounds which make it an interesting feedstock [46]. Nevertheless, a fraction of lignin is still present and the methane production is estimated at $240 \mathrm{~L} \mathrm{CH}_{4} / \mathrm{kg} \mathrm{VS}$. The production of lawn cutting from public and private gardens varied between 0.8 and $1.7 \mathrm{~kg} / \mathrm{m}^{2}$ (Table 3).

- From the study cases presented in Tables 1 and 2, other types of waste commonly produced, such as used cooking oil and greasy water, are also studied $[42,47]$. They are provided principally by canteens and restaurants with specific collection systems. This waste is defined by a high amount of fats which represent an important source of energy for the biomass. The TS is nearly $2 \%$ and the VS between 82 and $92 \%$ TS. The methane potential is also high with $700 \mathrm{~L} \mathrm{CH}_{4} / \mathrm{kg}$ VS (Table 3). Nevertheless, due to a fast production of VFA, during the anaerobic digestion, these wastes cannot be used alone and require an appropriate co-digestion (5-30\% VS of the feedstock) [35, 42, 47].

\section{Collection of deposits}

Two different ways can be used to collect organic waste in urban area. The first one is a centralized collection, where wastes from the project area are mixed with others from a global waste management site such as it, from a city or a region. The second one corresponds to a decentralized collection; the waste management is secluded to the global system, and it takes place generally in several local collection points. The concept of DESAR is linked to this second kind of process [16].

\section{Wastewater}

As example of these definitions, the Flintenbreite project (Fig. 1) is to be an autonomous collection and valorization of wastewater, decentralized from the city. Conversely, the wastewater management in Bo01 (Fig. 3) remains centralized with the global system from the city of Malmö. Traditionally, the collection of wastewater is centralized in WWTP. Community Toilet Complexes (CTC), in Nashik project, India, is another kind of wastewater collection system (Tables 1 and 2). Here, small storage units collect wastewater before its transport by specialized vehicles to the treatment unit [48]. Concerning wastewater collection process, the districts 
studied generally use separated-sourcing systems such as the vacuum toilet system. It collects only black or brown water, as in Flintenbreite. It decreases the water fraction of blackwater by almost $55 \%$ and at the same time concentrate the organic fraction [39]. Nevertheless, it also concentrates the fraction of $\mathrm{NH}_{4}-\mathrm{N}$ and significantly impacts the energetic cost of the system [35].

To perform the collection of wastewaters, the local context and the sewage network are also important, especially for the district scale. For example, the Flintenbreite pre-study [35] estimates that only a part of the theoretical blackwater producing is actually collected. In taking into account that the project is a residential district, people are in effect, not present during the day. Thus, in the absence of connection between the local treatment process and infrastructures such as enterprises, nurseries, and schools, a part of the theoretical matter is missing. The study also reveals the fraction of children in the population needs to be considered for district implementation. Indeed, it can significantly impact the quantity of wastewater collected in comparison with the estimated quantity.

\section{Green waste}

The deposit can be provided by private or public areas. Its collection is generally realized in specific stations or in bio-waste bins. To increase the collection of waste and perform anaerobic digestion, collaboration with green space service companies may be also necessary. The collection is highly dependent on the season, and supply is assumed to be available around 180 days per year [49]. Moreover, a good differentiation between lawn cutting and pruning scraps is needed to avoid a high lignin concentration. In the Jenfelder $\mathrm{Au}$ study, green wastes from the areas near the district are also investigated to increase the quantity recoverable.

\section{Food waste}

The current system corresponds to several collected points with vacuum systems or specific bins implanted in the urban area. Another way is the collection at source, directly from households, by the use of grinder systems located in the kitchen sink (kitchen waste). From canteens or restaurants, it involves sorting out the organic fraction and to store it before collection. Currently, specific collection solutions need to be developed in accord with urban disposition and quantity produced, such as the use of multi-compartment vehicles used in the Malmö district or vacuum truck with screw tank in Hammarby Sjöstad. This is particularly true for markets and wholesalers, which produce a non-negligible fraction of food waste, essentially from fruit and vegetable [50]. In Malmö, food waste is collected in two different ways, by the use of paper bags or directly from households, with sink grinders. Including the collection of all the kinds of food waste from the Malmö City, the number of collection points reaches 18,391 (Table 3). In Fullriggaren district (project 3 ), only $33-55 \%$ of the food waste produced by households is collected in the storage tank, after a grinder system. The rest of the food waste is either found in the residual waste $(37 \%)$ or passes through the retention tank and goes via the outlet to the sewer (23-33\%) [50]. This highlights the challenge to make and develop solutions in order to ensure a convenient collection of urban food waste. Nevertheless, as mentioned in studies, solid collaborations between municipalities and valorization facilities are of great importance for the success of this project $[51,52]$.

\section{Grease sludge and cooking oil}

The collection of sludge, from canteens or restaurants, is generally done by sludge grease traps, installed before the wastewater discharge system. It represents $530 \mathrm{col}-$ lection points in Malmö. The organic fraction composing the deposit is highly energetic; nevertheless, due to the low frequency of collection, a part of this is often lost in the wastewater flow. The collection of cooking oil is done directly in specific bins [35, 42, 47].

Resident participation in the collection is also an important point to ensure a good recovery of organic waste. As realized in Malmö's districts (Tables 1 and 2), sensitization could be provided to improve civil actions. Some collection systems are also favored by local inhabitant such as the grinder solution, more popular than paper bags (project 3). "Retourette" ${ }^{2}$ or "Recycling shop" on Eva-Lanxmeer (project 2) is another example of process at the disposal of inhabitants to encouraging the collection of among others, food waste and green wastes.

Commonly, centralized process is linked to one large-scale plant and decentralized process to small-scale units. Moreover, collection processes are often linked to preexisting or common installations, integrated in the urban area. In Hammarby Sjöstad, the district used the local pre-existent installation (WWTP) to perform its model of loop energy recovery. Nevertheless, these notions depend on the scale considered: An entire district with autonomous collection system as Eva-Lanxmeer project is decentralized from its city management. But its dwellings are still centralized in a same collection system. In another scale, the AD pilot in Sneek or the composting process in Allermöhe district was built with just a fraction of the dwellings involved in the DESAR process $[53,54]$.

To well understand the implications of the different ways to collect waste and their benefits, comparative LCAs can be realized. For example, the thesis of Bernstad in 2012 investigates the topic of food waste valorization with a focus on a residential area in southern Sweden [50]. It also considers other LCA studies on food waste 
management, related to the most beneficial way to conduce valorization process, collection system, and transport of waste [55-57].

\section{Storages and pretreatments}

If the objective is to deploy anaerobic digestion processes close to neighborhoods, the mastery of storage and pretreatment is crucial to avoid nuisances. Thus, they are impacted by their location in situ or ex situ. These processes are used to modulate the quality of waste and lead flow management, two main parameters in the reactor sizing. Storage is generally buried or simple hermetic tanks. Conversely, a large panel of processes could be used for pretreatment, depending on types of waste and characteristics needed. These processes principally reduce or degrade the non-usable fraction of wastes and thus increase their degradability [58]. Depending on national regulations, sanitation pretreatment must be needed for hygienic purposes, as in Germany or France.

In the case of a wastewater collection system connected to an anaerobic unit, as in Flintenbreite, the storage unit built in situ has two objectives: a buffer zone as pretreatment for the organic matter and a tank to modulate the inputs going to the digester $[59,60]$. In the Nashik project, India (Tables 1 and 2), to avoid rural defecation and to valorize the blackwaters, 200 (then 400) septic tanks are installed as local collection and storage units. This approach offers a sanitation aspect and a solution to limit nuisance from blackwater while awaiting its transport to anaerobic treatment [52]. The use of blackwater storage tanks in combination with pasteurization pretreatment or acidogenic hydrolysis was also studied. Results showed that a pretreatment at $24 \mathrm{~h}$ at $55{ }^{\circ} \mathrm{C}$ or $1 \mathrm{~h}$ at $70{ }^{\circ} \mathrm{C}$ is necessary to inactivate pathogens in waste [35]. In the Eva-Lanxmeer project, pre-acidification should have resulted in an efficient pretreatment, low cost in energy (project 2). Nevertheless, special attention must be paid to the control of VFA concentration. Pre-acidification is also used to increase the COD particulate and enhance biogas production. When the pretreatment cannot be installed in situ, it is generally located in a specific complex or facility after the transport process. WWTP is a common example of storage, pretreatment, and ex situ valorization unit. In the Nashik project (Tables 1 and 2), the storage of wastewater is realized in the project area but its pretreatment unit is installed, ex situ, close to the anaerobic digester. Thus, the installed unit is used to settle sewage water and mix the collected sludge with food waste, prior a possible sanitation process and the AD unit.

Pretreatment and storage of food waste depend to the collection realized. Malmö districts (project 3) provide an example of two different processes. The first one is the use of collection bags and mechanical pretreatment to sort out the organic fraction. The second one is a collection by sink grinder and storage in separation tanks. Nevertheless, the first pretreatment can highly impact the quantity of waste valued. As an example, the BO01 study (project 3 ) firstly used a mechanical pretreatment which, without a good monitoring, refused up to $60 \%$ of the weight of the TS, due to the presence of contaminant objects. Concerning the second way, grinder system and separation tank were also included. The grinder system provides a reduction of particle sizing and increases the degradability of the waste treated. The separation tank is here considered as pretreatment due to its effect on waste. Indeed, as shown in Fullriggaren during the 20 days of storage, a hydrolysis step is also performed [61]. Ex situ pretreatment of food waste is also observed in Kristianstad, Sweden (Fig. 3 and Tables 1 and 2) in order to increase the degradability of feedstock by creating liquid food waste [23, 61].

Concerning green waste, due to the difficulties involved in shredding lawn cuttings, Hertel et al. [42] demonstrate that to produce an easily pumpable, juice, the grass cuttings could be pressed to extract organic compounds (85$95 \%$ of total lactic acid and about $55-65 \%$ of crude protein can be extracted). Maceration with another waste such as blackwater to facilitate shredding has also been experimented with success [46]. Moreover, the seasonality of the waste, generally between summer and autumn, raises the need of specific storage. Commonly, green waste is conserved in vacuum bags, ball silos, or tanks in anaerobic conditions such as ensilage [46, 62].

In view of observations from the in situ and small-scale cases, storage and pretreatment units have a major limitation. Indeed, due to their location in the urban area, they need to be totally monitored to avoid nuisance for local dwellings. In Montpellier, an in situ process with a large-scale dimension, the project reports present some example of these nuisances. Indeed, consequently to some defects of construction and a difficult context of implementation, presence of vermin and olfactory issues were observed. Thus, significant investments such as biofilters were needed to reduce them. Flintenbreite, Eva-Lanxmeer, and LEAP project present in situ model of storage and pretreatments, jointly applied with low energy-consuming processes, to increase the benefit for valorization system (Tables 1 and 2). In small-scale implementation, the size reducing of unit is also needed. Nevertheless, feedback on blackwater and kitchen waste shows that hydraulic load is more limiting for the anaerobic process than the organic load. Indeed, even with a vacuum toilet, the low VS of blackwater (Table 3) needs to be considered to the dimension and the integration of the anaerobic digestion system [35]. Grey water presents the same problem, which it explains the use of bioflocculation pretreatment [38]. 


\section{Anaerobic digestion processes}

From processes used in the 15 case studies present in Tables 1 and 2, a large majority of them is fed by a mix of waste. Their AD is also mainly operated in wet conditions (DM $>20 \%$ ), due to the frequent using of wastewater in the mix. In comparison with dry conditions, wet condition is often defined as beneficial to biogas production. It also decreases the HRT and requires less energy for agitation than dry processes. Despite that, the size of the reactor in wet conditions is generally higher due to the water fraction employed. This last condition is especially impacting for the integration at district scale. Nevertheless, the dry process is more difficult to study and manage than wet conditions. Less frequently observed in urban waste implementation, two examples of dry process are however presented with the food waste anaerobic digestion plant in Montpellier, sizing for the wastes from 450,000 inhabitants, and Freiburg im Breisgau, Germany, sizing for 600,000 inhabitants (Tables 1 and 2). Conversely, the co-digestion of food waste from Bo01/Fullriggarens districts (Fig. 3) is pretreated to get a liquid feedstock and allows to lead anaerobic digestion in wet conditions.

The dimensions observed for the size of reactor are closely related to the wastes treated, the number of dwellings considered, the operational conditions, and the context of integration. Eva-Lanxmeer project (project 2) and its 250 lodgings foresaw a co-digestion of $1075 \mathrm{~m}^{3} /$ year with an HRT set at 20 days and considered a minimal size for its reactor to $70 \mathrm{~m}^{3}$. In Flintenbreite (project 1), it is 117 lodgings for a co-digestion and a reactor estimated respectively at $1200 \mathrm{~m}^{3}$ of waste/year and $73 \mathrm{~m}^{3}$ (HRT between 21 and 24 days). In Nashik, the reactor is dimensioned to $1300 \mathrm{~m}^{3}$, to treat with an HRT of 35 days, 30 tons/day of wastewater from 200 to 400 CTC, and food waste from 1350 local hotels. Similarly, the project in Jenfelder Au foresee a $900 \mathrm{~m}^{3}$ reactor to treat, with an HRT of 25 days, $30 \mathrm{~m}^{3} /$ days of wastes produced by 2000 inhabitants. When the anaerobic processes are outside the district, as in Bo01/Fullriggarens, Södertörn biogas unit or Freiburg im Breisgau, ${ }^{3}$ the size of the reactors encountered is even higher and correspond to large-scale unit (Tables 1 and 2).

Regarding the technology used in the 15 case studies (Tables 1 and 2), two kinds of reactors are identified to perform wet anaerobic digestion. Indeed, UASB and CSTR are installed or foreseen in Bo01/Fullriggarens, Sneek, Flintenbreite, Jenfelder $\mathrm{Au}$ project, and Hammarby Sjöstad (WWTP) case studies (Tables 1 and 2). The first one is characterized by a low risk of leaching and an important fraction of biomass. It is used to treat wastewater and its sludge [63]. UASB reduces retention time or reactor size and known to produce a good quantity of biogas $[31,63]$. The second one is especially used to treat waste with high concentrations of TSS or TS (3-10\%), which can be assumed to be the situation with co-digestion in a district area [35]. Its process is simple and known as stable and relatively easy to carry out. However, other technologies may be envisaged, such as anaerobic Membrane Bioreactor (MBR) foresee in the new biogas unit of Henriksdal or a two-stage reactor, as used in Singapore [64]. Concerning the two projects which use a dry anaerobic digestion, a Valorga ${ }^{\circ}$ process is observed (Tables 1 and 2).

HRT is a main parameter in reactor management due to its link with installation size, post-treatment needed, and quantity of waste treated. Indeed, the HRT is influenced by the organic loads and related to the reactor capacity and time required to achieve a satisfactory organic degradation and biogas production. Despite the differences observed in terms of substrates and loads used, HRT is set around 15-30 days, in relation with the methane production and the operational costs. Moreover, a study from the Flintenbreite project shows that long HRT (> 15 days) leads to process stabilization against shock loads for blackwater digestion [35]. Nevertheless, it can also be drastically reduced for specific feedstock or reactor technology, for example, the studies from Sneek district investigated the AD and aerobic digestion of greywater with an HRT $<1$ day.

According to Tables 1 and 2, the 15 AD processes observed are mainly done at mesophilic temperature, close to $35^{\circ} \mathrm{C}$. Reactor heating is generally achieved through a fraction of the biogas produced. Mesophilic temperature seems to offer a good balance between performance and cost. Some projects investigate the anaerobic digestion process at 20 or $25^{\circ} \mathrm{C}$, with the objective of lowering energy consumption. Unfortunately, it generally appears to be harmful for the biogas production and for small-scale integrated unit. Indeed, it increases the retention time needed for digestion and consequently the reactor sizing [32]. Regarding thermophilic temperature $\left(55^{\circ} \mathrm{C}\right)$, a rise in the biogas production and a reduction of the HRT is generally assumed. Nevertheless, the energy consumed to maintain the temperature in the reactor needs to be considered and could lead to an economical unsustainability. In a study about Malmö wastes valorization, thermophilic condition also results in instable anaerobic reactions for some kinds of feedstock [47]. Nevertheless, as a functional example, the ex situ AD process in Freiburg is still in operation after several years, which indicates the feasibility of the thermophilic process in certain conditions. Thermophilic condition is also forthcoming in Hammarby Sjöstad WWTP, which seems to indicate prevalence in large-scale implementation $[65,66]$.

Regarding large-scale processes, the fluctuations of the incoming matter are compensated by the quantity used. Thus, co-digestion appears not mandatory such as in the 
Freiburg im Breisgau plant ${ }^{3}$. Parameters and operational conditions such as reactor technology, size of unit, temperature, or HRT are also higher and generally lead to ex situ unit (Tables 1 and 2). Conversely, in situ processes are often carried out by small-scale implementations and a limited number of parameters (and processes) focused on reducing the reactor dimension, to increase the integration of the valorization unit. Hammarby Sjöstad WWTP and Montpellier projects still remain exceptions in the case studied, with their large-scale facilities implanted inside an urban area.

\section{Post-treatment, nutrient recovery, and energy saving Digestate valorization}

The use of digestate after anaerobic digestion raises some practical questions. Due to its composition of $\mathrm{N}$ and $\mathrm{P}$, digestate is a good substrate for soil fertilization. Nevertheless, except in the presence of urban farming, digestate cannot be used directly in the district areas. Moreover, the use of wastewater as feedstock generally involves a step of solid-liquid separation. It is assumed that digestate is comparable to an organic fertilizer, its solid phase including high concentration of $\mathrm{N}$ and $\mathrm{P}$ available, and the separated liquid fraction is concentrated in $\mathrm{N}$ and $\mathrm{K}[29,67]$.

From Figs. 1, 2, and 3, composting is the most popular option to treat the remaining solid fraction. Economically, the process is relevant by the production of fertilizer and does not need a high energy demand. However, it consumes organic matter and $\mathrm{N}$ fractions [68]. Another option is to dry the digestate after ammonium nitrification or addition of sulphuric acid to avoid the nitrogen loss [30]. This process concentrates nutrients into a powder and decreases the microbial activity; nevertheless, in the absence of heat recovery system, it is expensive in terms of energy. In Sweden, the Södertörn biogas unit (Tables 1 and 2) uses an evaporation treatment to remove the water fraction of digestate produced. Anyways, legislation can restrain the use of digestate produced by anaerobic digestion. As example, if the feedstock includes animal by-products, in Europe, sanitation process is mandatory. Consequently, additional processes may be employed to sanitize or achieve the digestate degradation and then reach these discharge standards [19]. Generally, to be used as fertilizer, compost has to reach standards qualities too.

Several techniques are used to extract usable compounds directly from digestate, especially if the soil area is far from the post-treatment unit. From Sneek and Jenfelder Au's projects, the chemical recovery is studied to be done by respectively struvite precipitation and ammonia stripping $[28,46]$. From the liquid fraction, ammoniacal nitrogen can also be removed by stripping with sulphuric acid and recovered from the gaseous phase via scrubbing with an ammonium sulphate solution. The stripping process takes place at high temperatures and also leads to sanitizing the digestate [42].

\section{Biogas valorization}

Usually, the limitation for the biogas valorization corresponds to (i) the methane fraction; (ii) the cost of gas post-treatment such as $\mathrm{H}_{2} \mathrm{~S}$ removal, or upgrading by $\mathrm{CO}_{2}$ removal; and (iii) the transport of produced energy [69]. Even if processes are integrated within the district area, not all valorization solutions may be considered. In general, an option is selected in accordance with the proximity of energy users, the distribution network, the grant mechanisms, and the energy balance [70, 71]. The energy balance can be constructed with the heat and electricity needed for the process (pretreatment, self-consumption...), the methane concentration in biogas, and the gain in energy produced by the valorization solution studied [39, 72]. Three major processes are generally investigated, heat and electricity produced by a combined heat and power system (CHP) unit, gas production for the city network, and fuel production for vehicles. The $\mathrm{CHP}$ process with $\mathrm{CO}_{2}$ purification, specific to the Eva-Lanxmeer project (Fig. 2), could also be mentioned. The choice of these valorization processes mainly depends on economical aspect and local users' needs which are specific for each country [73]. To closely understand the choices made in the analyzed projects, legislations and grant mechanisms also must be considered.

Concerning the gas and fuel production, it requires a methane content of more than $95 \%$ and specific standards had to be reached (low humidity, low $\mathrm{H}_{2} \mathrm{~S}$, and siloxane concentrations) [69]. Thus, the upgrading post-treatment needed is its main limitation. It is generally admitted that the purification treatments of these two valorization processes are too expensive to be sustainable for a small quantity of biogas and consequently reserved to large-scale $\mathrm{AD}$ plants $[19,30]$.

As example, from project studies in Tables 1 and 2, only the Sjölunda, Henriksdal WWTP, and Kristianstad biogas plant, with respectively $6 \mathrm{AD}$ reactor of $16,000 \mathrm{~m}^{3}, 2 \mathrm{AD}$ reactor of $5000 \mathrm{~m}^{3}$, and 7 reactors for a total of $39,000 \mathrm{~m}^{3}$, have upgrading units to convert biogas in fuel [74]. Data available about Kristianstad indicate that $65 \%$ of the biogas produced are used as heat when $35 \%$ are converted in fuel [74]. The important quantity of biogas produced from these units enables an economic and sustainable valorization. These examples also demonstrate the impact of local users' needs and the effect of national grant mechanisms. Indeed, the Sweden energy transition policy emphasizes the fuel upgrading valorization $[24,25]$.

From Tables 1 and 2, many small- and large-scale units use CHP valorization. This process accepts a larger quality of biogas, needs low post-treatment, and a good yield in terms of energy generated is generally assumed. Thus, this valorization process is especially highlighted 
for small-scale implementation. Concerning the biogas quality, to avoid engineering knock-out, methane fraction should be at least of $45 \%$ (especially $30 \%$ with the use of micro-turbines). Nevertheless, CHP process generally limited the $\mathrm{H}_{2} \mathrm{~S}$ fraction in biogas and the local grid needed to use the heat and electricity produced [69, 75]. As example of implementation, in Montpellier, the $11,800,000 \mathrm{~m}^{3}$ of biogas produced annually are threat by a CHP unit and the heat and electricity produced are brought to local apartments and infrastructures (hospital). The Nashik project with an ex situ centralized unit estimated the daily production of biogas between 1600 and $2100 \mathrm{~m}^{3}$, valorized with a CHP unit [76]. In these later cases, the local users' needs seem stronger in terms of heat and electricity production than fuel or city gas. CHP is also foreseen in small units, as the Flintenbreite and Eva-Lanxmeer projects, and used in the Sneek project. Conversely, of large-scale units, as previously mentioned, methane productions are here lower but the integration in the district area offers a local grid to use the heat and electricity produced. In Flintenbreite, based on the results of Wendland [35], the production is expected to be $4700 \mathrm{~m}^{3} \mathrm{CH}_{4} /$ year and $22,500 \mathrm{~m}^{3} \mathrm{CH}_{4}$ /year for maximal conditions and additional co-digestion. In Eva-Lanxmeer project, the production was expected to be close to $27,000 \mathrm{~m}^{3}$ biogas/year. At Sneek, the studies produced between 12 and $14 \mathrm{~m}^{3} \mathrm{CH}_{4} / \mathrm{cap} /$ year [39].

\section{District approach and conception}

To develop anaerobic digestion projects with the objective of treating waste in urban areas, the stakeholders must consider not only the technical aspects but also the social, political, and economic context. For example, wrongly performed, the process could cause nuisance to local inhabitants. Alongside this fact, the process is easily damaged in case of incorrect utilization by the inhabitants (such as the use of antimicrobial household products in toilet cleaning). Concerning the context of projects analyzed in Tables 1 and 2, many of them support national environmental policies and energy transition. They are generally initiated by a grouping of organizations, municipalities, universities, or corporations. Nevertheless, among these projects, the observations of abandoned processes reveal that financial constraints are strongly limiting for the analyzed projects, especially in the twentieth century. For example, in Germany, the first major integrated anaerobic treatment project started in the Vauban district of Freiburg ${ }^{3}$ which unfortunately was abandoned due to the bankruptcy of the company in charge of carrying out the process. The project was therefore carried forward, in the eco-district of Lübeck and further with Jenfelder Au in Hamburg (Tables 1 and 2).
When a project is situated in an urban setting, technologies are generally limited by the available area. Consequently, in situ processes are often present in small-scale processes, with a limited installation size to improve their integration. Nevertheless, due to financial aspects and limited available area in district location, it can be impossible to reserve land exclusively for a valorization platform. For these reasons, to our knowledge, many of the eco-district projects developed in the last 5 years do not include DESAR concepts. From Tables 1 and 2, it can be observed that municipal waste management systems for more than 100,000 people or with a high urban density currently lead to ex situ processes. Thus, autonomous waste management systems, constructed especially to be integrated at district scale, are generally limited to new building projects or low urban density projects, with valorization unit sizing for 100-2000 people. Some exceptions are still observed depending to pre-existent management system or specific integration context. Concerning the Hammarby Sjöstad WWTP, with a large-scale in situ process, it seems that the historic presence of a WWTP unit explains this particular model. Concerning the Montpellier case, the localization responded to strong issues about waste management and transport, which led to urban integration. Conversely, the BO01/Fullriggaren districts present a limited number of dwellings and an effective system of collection and waste management. Nevertheless, it seems that the proximity with existing $\mathrm{AD}$ units leads to an ex situ valorization process. A solution to increase the integration of projects and increase the energetic benefits seems to be to combine anaerobic digestion with other waste (pre)treatments, in small integrated plant, following the example of Noorderhoek (Sneek) and Eva-Lanxmeer project, which concentrate their waste valorization systems into respectively a garage or one building [54, 77].

The perception of inhabitants about the valorization process is also important in terms of integration in a district scale [78]. In the Netherlands, the Eva-Lanxmeer district remains a model of social participation by involving inhabitants in the politics of the district and also in the urban farming program. Indeed, the population has the preponderant role in the development and preservation of their neighborhood life. It also should be noted, despite the abandonment of the anaerobic digestion process, that the initial project associated an innovative social dimension by involving urban and rural/ agricultural cooperation. The advantages of involving inhabitants in a valorization project are also demonstrated by the Brest case study, a composting process in situ using several small units. There, the participation of schools and associations, supported by the established policy, led to strong community involvement and 
longevity of the process. Indeed, the awareness of young generations ensures a follow-up of good practices and integration of the process with a long-term vision. In the BedZed village, an audit, questionnaires, and measurements were carried out on the population living there. The social role of this project was highlighted by these results. Indeed, the energetic consumption of the district and the awareness of people about ecological practices appeared better than the mean of the country. Recently, other examples are emerging such as the community project in London, which involves the will of its inhabitants to transport their own organic waste to a common anaerobic digester [79]. It is also worth mentioning the participatory financing of anaerobic digesters fed by waste from cities and farmers in France [80]. In Sweden, the integration or reject of management system and innovative processes in Hammarby Sjöstad district is exposed by the work of Pandis Iveroth et al. [81], which details the influence of economic, social, and politic actors involved.

Indeed, politics also has an essential role from the financial aspects via grants mechanisms and institutional support. Pan et al. in their work highlight the implications of political decision in the development or the abandon of the DESAR concept. It can be observed that energy transition lead by international countries in the twentieth century has resulted in the construction of a large number of eco-building studies mentioned in this paper [18].

The scientific community is another main actor at the origin of eco-district projects. Indeed, the support of a local university is often prevalent in the case studies. This could concern the realization of pre-studies or ensure a follow-up of processes, as respectively in Germany or Sweden (project 1 and 3).

Lastly, we want to mention that from today and with the aim of producing recovery loops from organic waste, some different kinds of projects have studied or emerged. The Greenhouse Village concept, which combines urban districts and farms, is an example of model, based on the AD process, for hypothetical self-sufficient neighborhood [82, 83]. The integration of DESAR concepts in ecofriendly districts is not only focused on small anaerobic digestion [84]. Projects have also presented urban farming concepts, Living Machine ${ }^{1}$ processes, as in BedZED district (London) [85, 86], passive habitations, "zero waste" projects, corporate gardens, and forest cities [7, 12, 53, 87]. To this end, the realization of LCA methods seems pertinent as an approach to determining the environmental impact of the valorization systems in the pre-studies [50, 88]. LCA needs to take some hypothesis into account but provides multi-criteria answers to one question. For example, the energy valorization of food waste in the Hong Kong context, published by Woon et al. [89], takes human health and impacts on the ecosystem into account, to conclude that biogas valorization in fuel needs to be emphasized in this context. Indeed, other elements could be analyzed depending on the selected approach and then determine the impact or benefits of, among others, processes selected in the waste management system. In integrated project, the whole process is involved and anaerobic digestion has to be considered from waste collection to digestate utilization.

\section{Conclusions}

This paper presents a comparative study of anaerobic digestions and valorization treatments used in 15 urban projects. For understanding the elements which lead a waste management system, three comprehensive projects are investigated. Technical, economic, political, and social elements available are considered. Based on these results, the leading steps identified are discussed from the realizations of the 15 cases selected. The comparative analysis is performed with the objective to gain feedback about (i) the ways to carry out the processes, (ii) the improvements, and (iii) the limits already identified about urban $\mathrm{AD}$ and thus bring beneficial elements to future projects. The main outputs identified as essential for the anaerobic digestion process in urban districts are:

- Two ways are identified to implement urban AD, in situ management, which generally led in small processes integrated at district scale, and ex situ management with waste transported to large plants located outside of the urban area.

- Three typical sorts of waste are used for AD: blackwater, green, and food waste generally after grinding or shredding processes. Nevertheless, other wastes are investigated to perform co-digestions, such as greasy water or greywater [39, 42, 47].

- A strong and efficient collect, storage, and pretreatment network is necessary to supply a regular quantity of waste, with an optimal quality, to the process. The reduction of non-usable matter such as water in wastewater is essential to limit the size of the processes.

- Small-scale anaerobic digestion integrated in situ seems to be favored for low-density districts with construction or reconstruction of dwellings. In the case of already constructed dwellings with centralized waste management or high-density project, ex situ processes could be more convenient, especially if it involves the use of wastewater.

- Co-digestion appears to be optimized for wet process, with mesophilic temperature and HRT near to 20 days. Using a mix of waste as feedstock is also 
a way to stabilize the reaction in the absence of dilution effects (as in large-scale).

- Digestate is used to produce fertilizer, due to its nutrient fractions available. After filtration, the liquid part extracted could be treated by chemical process, wetland, or classical aerobic digestion post-treatment. Composting is mainly promoted as digestate treatment for the solid fraction.

- The quantity of biogas produced by a small unit involves that energy recovery is mainly done by CHP to transform biogas into heat and electricity. Ex situ, the valorization process seems to have been chosen depending on local users' needs, grid, or energy transition policy.

- A local structure of valorization, as anaerobic digestion or composting in situ, has some beneficial social impacts. The district scale is especially appropriate to social and local initiatives.

- The creation of DESAR concepts requires the involvement of scientific, economic, political, and social communities with a multi-disciplinary and systemic approach [81, 84, 90, 91].

To improve knowledge of anaerobic digestion on an urban scale, some further investigations could be suggested.

- The study of waste selections would consider the non-usable fraction of waste and the impact of the collection conditions.

- Due to the proximity to households and the area available at district scale, it seems advisable that storage and pretreatment processes are investigated for in situ projects. The aims identified are to decrease the size of the units, increase performances and nuisance control, and evaluate the impact on the quality of the feedstock.

- With the development of urban agriculture projects, the additional amount of waste also needs to be considered [92].

- Finally, to increase the sustainability of projects with a long-term vision, a multi-criteria and systemic study such as LCA method seems pertinent during the pre-study stage $[88,93-96]$.

\section{Endnotes}

${ }^{1} \mathrm{~A}$ "Living Machine" is an infra-structure where a complete ecosystem is created, with bioremediation objectives. The close-circuit, with the supply of microbial communities, plant, and/or fish, provides a management of nutriments from soils, wastewater, or specific feedstock. It results in a biological treatment and the production of by-products such as clean water, animal feed, or vegetable $[75,97]$.
${ }^{2}$ In "Retourette," people are invited to supply many kinds of recoverable waste and put it in specific "bins." The concept is to collect a large quantity of recoverable waste in one room designed to serve as a place for waste separation. It often takes place alongside a supermarket to increase the quantity available for a valorization chain [41].

${ }^{3}$ It should be noted that anaerobic digestion of food waste is still performed in Freiburg. It concerns waste from a large part of the Breisgau-Hochschwarzwald and Lörrrachsoit regions, approximately 600,000 inhabitants.

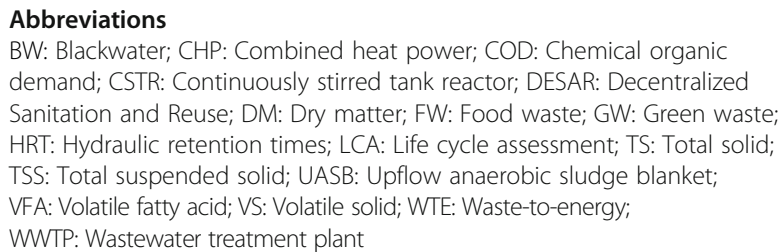

\section{Acknowledgements}

We would like to acknowledge the financial support of the Pays de la Loire region for the thesis from which this work was extracted. Also, we would like to acknowledge all persons contacted during the data collection, who, in all different ways, participated in the discussion of this paper. A special thanks to the three persons, including the language editing service GLAT (IMT Atlantique, France), who took of their time to improve the English language of this paper. Generally, we also would like to address a sincerely thought for colleagues and acquaintances who improved the quality of this document.

\section{Funding}

The thesis from which this work is extracted is co-funded by the Pays de la Loire region (FR), for the remuneration of the Ph.D. student and the CSTB Nantes. Technical necessities were supplied by CSTB Nantes and GEPEA in the laboratory of IMT Atlantique.

\section{Availability of data and materials}

The CSTB is a public agency; consequently, data about research finding is available by directly contacting the Research and Development Direction at Champs-sur-Marne, France or on the website, http://www.cstb.fr/.

\section{Authors' contributions}

JRBA did the data collection and the analysis and drafted the manuscript. AM contributed to the sorting and analysis of data and drafting of the manuscript. AL made contributions to the conception of this paper especially concerning the approach and objectives. TL made contributions to the text by proofreading and gave advice to improve consistencies of discussion. YA made substantial contributions to the drafting of the manuscript by his critical reviews and his important participation in the debates and final draft of the published version. All authors read and approved the final manuscript.

\section{Authors' information}

J.R.B.A is a Ph.D. student working for the CSTB Nantes with the technical support of GEPEA (UMR CNRS 6144), IMT Atlantique.

Ethics approval and consent to participate Not applicable.

\section{Consent for publication \\ Not applicable.}

\section{Competing interests}

The authors declare that they have no competing interests.

\section{Publisher's Note}

Springer Nature remains neutral with regard to jurisdictional claims in published maps and institutional affiliations. 


\section{Received: 13 March 2018 Accepted: 30 August 2018}

\section{Published online: 27 September 2018}

\section{References}

1. Moisan F. Energy climate visions 2030/2050: which ways of life for tomorrow? [Internet]. 2014. Available from: http://inis.iaea.org/Search/search. aspx?orig_q=RN:46066408

2. World Cities Report (2016) Urbanization and development: emerging futures [Internet]. Unhabitat for a better urban future, Nairobi, p 264 Available from: http://wcr.unhabitat.org/wp-content/uploads/2017/02/WCR-2016-FullReport.pdf

3. Kampelmann S (2016) Mesurer l'économie circulaire à l'échelle territoriale. Une analyse systémique de la gestion des matières organiques à Bruxelles. Rev OFCE 145:161-184 Available from: https://www.cairn.info/revue-de-Iofce-2016-1-page-161.htm

4. Reverdy AL (2013) Anaerobic digestion of sewage sludge: overview of the French situation. Water Pract Technol 8:180-189 Available from: https:// iwaponline.com/wpt/article-abstract/8/2/180/21385/Anaerobic-digestion-ofsewage-sludge-overview-of?redirectedFrom=fulltext

5. Netherlands Entreprise Agency. Sustainable biomass and bioenergy in the Netherlands [Internet]. 2015. Available from: http://english.rvo.nl/sites/ default/files/2016/05/Sustainable-biomass-bioenergy-netherlands.pdf

6. Fraker H, Emeritus D (2013) Why urban sustainability at neighborhood scales, p 45

7. Fraker $\mathrm{H}$ The hidden potential of sustainable neighborhoods [Internet] 2013. Available from: //www.springer.com/gp/book/9781610914093

8. Jacobs J. The economy of cities. First Pr. edition. Vintage; 1970. ISBN: 978-0394-70584-2

9. Jacobs J. Cities and the wealth of nations. Reprint edition. Vintage; 1985 ISBN: 978-0-394-72911-4

10. Jacobs J. The death and life of great American cities. Reissue edition. Vintage; 1992. ISBN: 978-0-679-74195-4

11. Clark WW (ed) (2009) Sustainable communities [Internet]. Springer New York New York Available from: http://link.springer.com/10.1007/978-1-4419-0219-1

12. Bringault A, Eisermann M, Lacassagne S. Vers des Villes 100\% énergies renouvelables et maitrisant leur consommation Pistes de réflexion et d'action [Internet]. 2016. Available from: http://www.territoires-climat.ademe. $\mathrm{fr} / \mathrm{sites} /$ default/files/publication_vers_des_villes_100_enr-web.pdf

13. Jabareen YR (2006) Sustainable urban forms: their typologies, models, and concepts. J Plan Educ Res 26:38-52 Available from: http://jpe.sagepub.com/ cgi/doi/10.1177/0739456X05285119

14. Hough M (2004) Cities and natural process: a basis for sustainability [Internet]. London: Routledge. Available from: https://www.taylorfrancis. com/books/9781134426836

15. Berg PG, Nycander G (1997) Sustainable neighbourhoods-a qualitative model for resource management in communities. Landsc Urban Plan 39 117-135

16. van Timmeren A, de Graaf PA, de Vries G (2005) Spatial conditions for the integration of combined decentralised energy generation and waste (water) management in city districts. WIT Trans Ecol Environ; 84. Available from: http://www.witpress.com/elibrary/wit-transactions-on-ecology-and-theenvironment/84/15507

17. Kunkel P. Environmental policy in Freiburg. 2011. Available from: https:// www.freiburg.de/pb/site/Freiburg/get/params_E-833712304/743186/ greencity_environmental_policy.pdf

18. Pan S-Y, Du MA, Huang I-T, Liu I-H, Chang E-E, Chiang P-C (2015) Strategies on implementation of waste-to-energy (WTE) supply chain for circular economy system: a review. J Clean Prod 108(Part A):409-421 Available from: http://www.sciencedirect.com/science/article/pii/S0959652615008574

19. Spijker E, Jepma C, Eisenack K, Brunekreeft G. A level playing field for the European biogas and biomethane market [Internet]. GROEN GAS - GRÜNES GAS; 2015. Available from: http://jin.ngo/images/jin/publications/final_ report_interreg.pdf

20. Hofmann F, Stolpp S. Biogas in Germany development, technology and benefits [Internet]. Warsaw; 2016. Available from: http://philippinen.ahk.de/ uploads/media/Biogas_as_a_flexible_source_of_Renewable_Energy_Frank_ Hofmann.pdf

21. Dumont M. Biogas situation in the Netherlands [Internet]. Moss; 2012 Available from: http://task37.ieabioenergy.com/files/daten-redaktion/ download/publications/Workshops/10/Mathieu\%20Dumont_ Biogas\%20Situation\%20in\%20Netherlands.pdf
22. Klingstedt T, Gustavsson D, la Cour Jansen J. Modelling the COD reducing treatment processes at Sjölunda WWTP [Internet]. Lund University; 2015. Available from: https://lup.lub.lu.se/student-papers/search/publication/ 5368008. Accessed 31 Jan 2018

23. SYSAV BIOTEC. From food waste to new resources Sysav's pre-treatment plant for food waste [Internet]. Available from: https://www.sysav.se/ globalassets/media/filer-och-dokument/informationsmaterial-broschyrerarsredovisningar-faktablad-rapporter-etc/broschyrer-och-arsredovisningar-paandra-sprak/from-food-waste-to-new-resources.pdf

24. Swedish Gas Association. Biogas in Sweden [Internet]. Energigas Sverige; 2011. Available from: www.energigas.se. Accessed 2 Feb 2018

25. Backman M, Rogulska M. Biomethane use in Sweden. Arch Automot EngArch Motoryz [Internet]. 2016; Available from: http://archiwummotoryzacji. pl/index.php?option=com_am\&view=article\&id=104\&lang=pl

26. Chen Y, Cheng JJ, Creamer KS (2008) Inhibition of anaerobic digestion process: a review. Bioresour Technol 99:4044-4064 Available from: http:// linkinghub.elsevier.com/retrieve/pii/S0960852407001563

27. Sperling M von, CA de Lemos Chernicharo. Biological wastewater treatment in warm climate regions. Vol. 1: [...] [Internet]. London: IWA [u.a.]; 2005. Available from: https://www.iwapublishing.com/sites/default/files/ebooks/ 9781780402734.pdf

28. de Graaff MS. Resource recovery from black water [Internet]. 2010. Available from:http://library.wur.nl/WebQuery/wurpubs/fulltext/134979

29. Held J, Mathiasson A, Nylander A. Handbook for biogas valorisation in Swedish. 2008. Available from: www.lemvigbiogas.com/BiogasHandbook.pdf

30. Rehl T, Müller J (2011) Life cycle assessment of biogas digestate processing technologies. Resour Conserv Recycl 56:92-104 Available from: http:// linkinghub.elsevier.com/retrieve/pii/S0921344911001686

31. de Graaff MS, Temmink H, Zeeman G, Buisman CJN (2010) Anaerobic treatment of concentrated black water in a UASB reactor at a short HRT. Water 2:101-119 Available from: http://www.mdpi.com/2073-4441/2/1/101/

32. Kujawa-Roeleveld K, Zeeman G (2006) Anaerobic treatment in decentralised and source-separation-based sanitation concepts. Rev Environ Sci Biotechnol 5:115-139 Available from: http://link.springer.com/10.1007/ s11157-005-5789-9

33. Metcalf et Eddy Inc., Tchobanoglous G, Burton F, Stensel HD. Wastewater engineering: treatment and reuse [Internet]. London: McGraw-Hill Education - Europe; 2003. Available from: https://www.mheducation.com/highered/ product/wastewater-engineering-treatment-resource-recovery-metcalf-eddyinc-tchobanoglous/M0073401188.html

34. Miron Y, Zeeman G, van Lier JB, Lettinga G (2000) The role of sludge retention time in the hydrolysis and acidification of lipids, carbohydrates and proteins during digestion of primary sludge in CSTR systems. Water Res 34:1705-1713 Available from: http://www.sciencedirect.com/science/article/ pii/S0043135499002808

35. Wendland C (2008) Anaerobic digestion of blackwater and kitchen refuse. Ges. zur Förderung und Entwicklung der Umwelttechnologien an der Technischen Univ. Hamburg-Harburg, Hamburg ISBN: 978-3-930400-43-0

36. Sievers JC, Wätzel T, Londong J, Kraft E. Case study: characterization of source-separated blackwater and greywater in the ecological housing estate Lübeck "Flintenbreite" (Germany). Environ Earth Sci. 2016; 75. Available from: http://link.springer.com/10.1007/s12665-016-6232-y

37. Eriksson E, Auffarth K, Henze M, Ledin A (2002) Characteristics of grey wastewater. Urban Water 4:85-104 Available from: http://www.sciencedirect. com/science/article/pii/S1462075801000644

38. Hernández Leal L, Temmink H, Zeeman G, CJN B (2010) Bioflocculation of grey water for improved energy recovery within decentralized sanitation concepts. Bioresour Technol 101:9065-9070 Available from: http:// linkinghub.elsevier.com/retrieve/pii/S096085241001237X

39. Zeeman G, Kujawa K, Mes T, Hernandez L, Graaff M, Abu-Ghunmi L. Anaerobic treatment as a core technology for energy, nutrients and water recovery from source-separated domestic waste(water). Water Sci Technol. 2008; 57. Available from: https://doi.org/10.2166/wst.2008.101

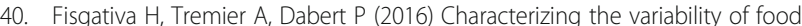
waste quality: a need for efficient valorisation through anaerobic digestion. Waste Manag 50:264-274 Available from: http://www.sciencedirect.com/ science/article/pii/S0956053X16300411

41. van Timmeren A, Röling LC (2003) Decentralised waste collection and separation in city districts and neighbourhoods, vol 67 Available from: https:/www witpress.com/elibrary/wit-transactions-on-ecology-and-theenvironment/67/2002. 
42. Hertel S, Navarro P, Deegener S, Körner I. Biogas and nutrients from blackwater, lawn cuttings and grease trap residues - experiments for Hamburg's Jenfelder Au district. Energy Sustain Soc. 2015; 5:29. Available from: https://doi.org/10.1186/s13705-015-0057-5

43. Fabbri D, Torri C (2016) Linking pyrolysis and anaerobic digestion (Py-AD) for the conversion of lignocellulosic biomass. Curr Opin Biotechnol 38:167-173

44. Monlau F, Sambusiti C, Antoniou N, Barakat A, Zabaniotou A (2015) A new concept for enhancing energy recovery from agricultural residues by coupling anaerobic digestion and pyrolysis process. Appl Energy 148:32-38

45. Yang H, Yan R, Chen H, Lee DH, Zheng C (2007) Characteristics of hemicellulose, cellulose and lignin pyrolysis. Fuel 86:1781-1788 Available from: http://linkinghub.elsevier.com/retrieve/pii/S001623610600490X

46. Kôrner I, Hertel S (2014) Experiences from the Jenfelder Au neighbourhood in Hamburg to utilize regional bioresources for energy provision. Moldova: Ener2i Energy and Innovation Workshop. Available from: https://ener2i.eu/ object/news/54/attach/Nortrag_Koerner-final.pdf

47. Davidsson A, la Cour Jansen J, Appelqvist B, Gruvberger C, Hallmer M (2007) Anaerobic digestion potential of urban organic waste: a case study in Malmö. Waste Manag Res 25:162-169 Available from: http://journals. sagepub.com/doi/10.1177/0734242X07075635

48. Dube R (2014) Waste to energy -Nashik, India (co-fermentation of kitchen waste and fecal sludge) [Internet]. Stockholm: World Water Week. Available from: http://docplayer.net/24326852-Presentation-from-the-2014-worldwater-week-in-stockholm.html

49. van Timmeren A, Sidler D, Kaptein M. Sustainable decentralized energy generation \& sanitation: case EVA Lanxmeer, Culemborg, the Netherlands. J Green Build. 2007; 2:137-150. Available from: https://doi.org/10.3992/jgb.2.4.137

50. Bernstad A (2012) Household food waste management-evaluations of current status and potential improvements using life-cycle assessment. Methodology

51. Valilescu MN, Wendland C, Isacu M. Towards safe water and sanitation in rural localities: appling the water safety planning methology in Manastiur, Romania. Ref S2SMALL-22676. 2017

52. Yadav JM, Dube R, Walther D, Pawar RK (2014) Waste to energy through cofermentation of organic waste and septage in Nashik: a close the loop cycle approach. Dtsch Ges Für Int Zusammenarbeit GIZ GmbH New Delhi India. 4:369-375. http://www.urbansanitation.org/live/hrdpmp/hrdpmaster/ hrdp-asem/content/e30293/e31169/e49811/e58876/WastetoEnergythrough cofermentationoforganicwasteandseptageinNashik-Aclosetheloop cycleapproach1.pdf

53. Rauschning G, Berger W, Ebeling B, Schöpe A. Ecological settlement in Allermöhe Hamburg, Germany. 2009. Available from: www.susana.org

54. Rovers J, Kroonen-Backbier B, de Haan JJ. Haal meer stikstof uit de bodem!: tips voor een optimaal stikstofgebruik op een aardbeibedrijf! Praktijkonderzoek Plant \& Omgeving BV; 2006

55. Finnveden $G$ (1999) Methodological aspects of life cycle assessment of integrated solid waste management systems. Resour Conserv Recycl 26: 173-187 Available from: http://www.sciencedirect.com/science/article/pii/ S0921344999000051

56. Finnveden G, Johansson J, Lind P, Moberg $\AA$ (2005) Life cycle assessment of energy from solid waste-part 1: general methodology and results. J Clean Prod 13:213-229 Available from: http://linkinghub.elsevier.com/retrieve/pii/ S0959652604000915

57. Clift R, Doig A, Finnveden G (2000) The application of life cycle assessment to integrated solid waste management: Part 1-Methodology. Sustain Dev 78:279-287 Available from: http://www.sciencedirect.com/science/article/pii/ S095758200070886X

58. Pérez J, Muñoz-Dorado J, de la Rubia T, Martínez J. Biodegradation and biological treatments of cellulose, hemicellulose and lignin: an overview. Int Microbiol 2002; 5:53-63. Available from: http://link.springer.com/10.1007/ s10123-002-0062-3

59. Münch E v. Overview of anaerobic treatment options for sustainable sanitation systems. BGR Symp "Coupling Sustain Sanit Groundw Prot. 2008. Available from: http://www.sswm.info/sites/default/files/reference attachments/MUENCH\%202008\%200verview\%20of\%20anaerobic\%20 treatment\%20options\%20for\%20sustainable\%20sanitation\%20systems.pdf

60. Münch E v. Ecological housing estate, Flintenbreite, Lübeck, Germany - draft [Internet]. 2009. Available from: www.susana.org

61. Bissmont M, Davidsson A (2015) Schott ABS. New collection system for food waste to biogas. Energiforsk Rep 100. Available from: http://ecosaver.se/ onewebmedia/Energiforsk001.pdf
62. Nizami A-S, Murphy JD (2010) What type of digester configurations should be employed to produce biomethane from grass silage? Renew Sust Energ Rev 14:1558-1568 Available from: http://www.sciencedirect.com/science/ article/pii/S1364032110000456

63. Zhao C. Effect of temperature on biogas production in anaerobic treatment of domestic wastewater UASB system in Hammarby Sjöstadsverk. 2011. Available from: http://www.diva-portal.org/smash/record.jsf?pid=diva2: 528241

64. Rajagopal R, Lim JW, Mao Y, Chen C-L, Wang J-Y (2013) Anaerobic co-digestion of source segregated brown water (feces-without-urine) and food waste: for Singapore context. Sci Total Environ 443:877-886 Available from: http://www.sciencedirect.com/science/article/pii/ S0048969712014404

65. Hellstedt C, Starberg K, Olsson L-E, Hellström D, Jonsson L, Mossakowska A. Increased biogas production at the Henriksdal WWTP [Internet]. 2009. Report No.: del_2.15_SVAB_v2. Available from: http://www.stockholm vattenochavfall.se/globalassets/pdf1/rapporter/avlopp/avloppsrening/d2.15_ svab_v2_20100518vfm.pdf

66. Stockholm Vatten och Avfall. Modernisation of Henriksdal wastewater treatment plant [Internet]. 2016. Available from: http://www.stockholm vatten.se/en/sfa-start/tunnel-and-wwtp/modern-wastewater-treatment/ upgrade-of-henriksdal-wastewater-treatment-plant/

67. Möller K, Müller T (2012) Effects of anaerobic digestion on digestate nutrient availability and crop growth: a review: digestate nutrient availability. Eng Life Sci 12:242-257 Available from: http://doi.wiley.com/10.1002/elsc.201100085

68. Alburquerque JA, de la Fuente C, Campoy M, Carrasco L, Nájera I, Baixauli C et al (2012) Agricultural use of digestate for horticultural crop production and improvement of soil properties. Eur J Agron 43:119-128 Available from: http://linkinghub.elsevier.com/retrieve/pii/S1161030112000834

69. Al Seadi T, Drosg B, Fuchs W, Rutz D, Janssen R (2013) Biogas digestate quality and utilization. Biogas Handb. Cambridge: Elsevier. p. 267-301. Available from: http://linkinghub.elsevier.com/retrieve/pii/ B9780857094988500129

70. Curry N, Pillay P (2012) Biogas prediction and design of a food waste to energy system for the urban environment. Renew Energy 41:200-209 Available from: http://linkinghub.elsevier.com/retrieve/pii/S0960148 111005957

71. Yentekakis IV, Goula G (2017) Biogas management: advanced utilization for production of renewable energy and added-value chemicals. Front Environ Sci 5:7. Available from: http://journal.frontiersin.org/article/10.3389/fenvs. 2017.00007/full

72. Warren K. A techno-economic comparison of biogas upgrading technologies in Europe. 2012;

73. Woon KS, IMC L (2016) A proposed framework of food waste collection and recycling for renewable biogas fuel production in Hong Kong. Waste Manag 47:3-10 Available from: http://linkinghub.elsevier.com/retrieve/pii/ S0956053X15002147

74. KLIMP. Biogas Kristianstad brochure 2009 [Internet]. Scribd. 2009. Available from: https://www.scribd.com/document/47459673/2-Biogas-Kristianstadbrochure-2009

75. van Timmeren A, Tawil M (2006) Integration of living machine and biogas plant case EVA Centre Lanxmeer, Culemborg. Switzerland: Geneva. Available from: https://www.researchgate.net/profile/A_Timmeren/publication/ 238662763_Integration_of_Living_Machine_and_Biogas_plant_Case_EVA_ Centre_Lanxmeer_Culemborg/links/0c9605283441c2b027000000/Integrationof-Living-Machine-and-Biogas-plant-Case-EVA-Centre-Lanxmeer-Culemborg.pd

76. Bhange HN, Gravit BK, Purohit RC, Ingle PM (2017) Energy production through co-fermentation of organic waste and septage in Nashik City, India. Int J Curr Microbiol Appl Sci 6:2788-2798 Available from: http://www.ijcmas. com/abstractview.php?|D=2200\&vol=6-4-2017\&SNo=322

77. van Timmeren A, Kaptein M, Sidler D. Workshop: the sustainable city. Europhys Lett. 2007; 54. Available from: https://www.researchgate.net/ profile/A_Timmeren/publication/228472384_SUSTAINABLE_URBAN_ DECENTRALIZATION_CASE EVA_LANXMEER_CULEMBORG_THE NETHERLANDS/links/0c9605283441c7b205000000.pdf

78. Roling $\mathrm{W}$, Timmeren AV. Introducing urban agriculture related concepts in the built environment: the park of the 21st century. 2005 World Sustain Build Conf Tokyo 2005. p. 27-29

79. LEAP. Anaerobic Digestion: Local Energy ADventure Partnership. Available from: http://communitybydesign.co.uk/pages/anaerobic-digestion. Accessed 2 Mar 2018 
80. OSER. Methamoly. 2017. Available from: http://enr-oser.fr/prod/wp-content/ uploads/2017/05/Methamoly.pdf

81. Pandis Iveroth S, Vernay A-L, Mulder KF, Brandt N (2013) Implications of systems integration at the urban level: the case of Hammarby Sjöstad. Stockholm J Clean Prod 48:220-231 Available from: http://linkinghub. elsevier.com/retrieve/pii/S0959652612004775

82. Wortman E, Kruseman IEL. De zonneterp-een grootschalig zonproject. InnovatieNetwerk Groene Ruimte en Agrocluster Utrecht; 2005

83. Mels AR, van Andel E, Wortmann E, Kristinsson J, Oei P, de Wilt J, et al. Greenhouse village, the greenhouse-powered, self-sufficient neighbourhood. Proc Int Conf Asia-Eur sustain urban Dev Chongqing Univ. 2006

84. Oteman M, Wiering M, Helderman J-K (2014) The institutional space of community initiatives for renewable energy: a comparative case study of the Netherlands, Germany and Denmark. Energy Sustain Soc 4:11

85. Hodge J, Haltrecht J (2009) BedZED seven years on the impact of the UK's best known eco-village and its residents [Internet]. London, BioReginal Available from: www.bioregional.com

86. Smith CS, Butler D (2008) Water management at BedZED: some lessons. Proc Inst Civ Eng - Eng Sustain 161:113-122 Available from: http://www. icevirtuallibrary.com/doi/10.1680/ensu.2008.161.2.113

87. Brest Métropole (2016) Les déchets à Brest métropole [Internet]. France: Brest Metropole. Available from: https://www.brest.fr/fileadmin/Documents/ Au_quotidien/agir_pour_l-environnement/Dechets/Rapport_Annuel_2016. pdf

88. Jernberg J, Hedenskog S, Huang C. An urban development case study of Hammarby Sjöstad in Sweden, Stockholm. 2015; Available from: http:// energyinnovation.org/wp-content/uploads/2015/12/Hammarby-Sjostad.pdf

89. Woon KS, Lo IMC, Chiu SLH, DYS Y (2016) Environmental assessment of food waste valorization in producing biogas for various types of energy use based on LCA approach. Waste Manag 50:290-299 Available from: http:// linkinghub.elsevier.com/retrieve/pii/S0956053X16300691

90. ADEME. Visions Energie Climat 2030/2050 Quels modes de vie pour demain ? [Internet]. 2014. Report No.: N 978-2-35838-629-6. Available from: http://www.ademe.fr/sites/default/files/assets/documents/visions-energieclimat-2030-2050-partie-1-2014-8102.pdf

91. ADEME. Mix de gaz 100\% renouvelable en 2050 ? [Internet]. ADEME; 2018. Available from: http://www.ademe.fr/sites/default/files/assets/documents/ france-independante-mix-gaz-renouvelable-010503.pdf

92. Röling W, van Timmeren A. Introducing urban agriculture related concepts in the built environment: the park $f$ the 21st century. 2012

93. Bisinella de Faria AB, Spérandio M, Ahmadi A, Tiruta-Barna L (2015) Evaluation of new alternatives in wastewater treatment plants based on dynamic modelling and life cycle assessment (DM-LCA). Water Res 84:99111 Available from: http://linkinghub.elsevier.com/retrieve/pii/ S0043135415300981

94. Buonocore E, Mellino S, De Angelis G, Liu G, Ulgiati S. Life cycle assessment indicators of urban wastewater and sewage sludge treatment. Ecol Indic. 2016; Available from: http://linkinghub.elsevier.com/retrieve/pii/ S1470160X16302291

95. Mezzullo WG, McManus MC, Hammond GP (2013) Life cycle assessment of a small-scale anaerobic digestion plant from cattle waste. Appl Energy 102: 657-664 Available from: http://linkinghub.elsevier.com/retrieve/pii/ S0306261912005776

96. Khoshnevisan B, Tsapekos P, Alvarado-Morales M, Rafiee S, Tabatabaei M, Angelidaki I (2018) Life cycle assessment of different strategies for energy and nutrient recovery from source sorted organic fraction of household waste. J Clean Prod 180:360-374 Available from: http://www.sciencedirect. com/science/article/pii/S0959652618302269

97. Todd J, Josephson B (1996) The design of living technologies for waste treatment. Mesocosms Ecol Eng 6:109-136 Available from: http://www. sciencedirect.com/science/article/pii/0925857495000542

98. Cours des Comptes. L'usine de traitement des déchets Amétyst de Montpellier : un pari sur un processus industriel complexe [Internet]. Cours des Comptes; 2017. Available from: https://www.ccomptes.fr/sites/default/ files/EzPublish/08-usine-traitement-dechets-Ametyst-Montpellier-Tome-1.pdf

99. Air Languedoc-Rousillon. UNITÉ DE MÉTHANISATION DES DÉCHETS MÉNAGERS AMÉTYST (MONTPELLIER) : SURVEILLANCE DES ODEURS ANNÉE 2014 [Internet]. ATMO; 2015. Available from: https://www.air-Ir.org/wpcontent/uploads/odeurs-amehyst-2014.pdf
100. Freiburg. GreenCity: Approaches to substainability [Internet]. 2016. Available from: http://www.freiburg.de/pb/site/Freiburg/get/params_E-680488302/ 640888/GreenCity_E2017.pdf

101. Valorga International. The Freiburg plant. Available from: http://proxy.siteo. com.s3.amazonaws.com/www.valorgainternational.fr/file/100524freiburgang4.pdf

102. KREIS. Das KREIS-Projekt: Versorgen durch Entsorgen [Internet]. 2012. Available from: https://www.fona.de/mediathek/pdf/KREIS_Broschuere_ web.pdf

103. Husain M, Chavhan FI, Navale K. Anaerobic digestion of biodegradable organics in municipal solid wastes in Nashik city. Inte Rnational Res J Eng Technol IRJET. 2016; 03 (Issue). Available from: https://www.irjet.net/ archives/N3/i2/IRJET-V312256.pdf

104. Prabhu MS, Mutnuri S (2016) Anaerobic co-digestion of sewage sludge and food waste. Waste Manag Res 34:307-315 Available from: http://journals. sagepub.com/doi/abs/10.1177/0734242X16628976

105. GIZ. Plant in Nashik [Internet]. 2018. Available from: https://www. international-climate-initiative.com/fileadmin/Dokumente/2017/171201_ WtE_Brochure.pdf

106. Persson B, Arkus. The Western Harbour: experiences and lessons learned from Malmö, Sweden [Internet]. Malmö: Arkus; 2013. Available from: https:// copac.jisc.ac.uk/id/40442984?style=html

107. Austin G (2013) Case study and sustainability assessment of Bo01, Malmö, Sweden. J Green Build 8:34-50 Available from: http://www. journalofgreenbuilding.com/doi/abs/10.3992/jgb.8.3.34

108. VA SYD. Sjolunda, VA SYD [Internet]. 2016. Available from: http://www.vasyd. se/-/media/Documents/Broschyrer/Vatten-och-avlopp/Avloppsreningsverkoch-skyddsinformation/SjolundaReningsverkEnglish201609Webb.ashx

109. Ojala P (2017) Profitability factors of biogas plants, p 62 Available from: https://www.theseus.fi/bitstream/handle/10024/128503/Ojala_Pia. pdf?sequence $=1$

110. GreenGasGrids. Biogas ur gödsel, avfall och restprodukter - goda svenska exempel [Internet]. 2008. Available from: http://www.greengasgrids.eu/ fileadmin/greengas/media/Markets/Sweden/BiogasinfoEngGodaExempel.pdf

111. Paing J, Guilbert A, Gagnon V, Chazarenc F (2015) Effect of climate, wastewater composition, loading rates, system age and design on performances of French vertical flow constructed wetlands: a survey based on 169 full scale systems. Spec Issue 5th Int Symp Wetl Pollut Dyn Control 80:46-52 Available from: http://www.sciencedirect.com/science/article/pii/ S0925857414005655

112. Zeeman G, Lettinga G (1999) The role of anaerobic digestion of domestic sewage in closing the water and nutrient cycle at community level. Water Sci Technol [Internet] 39:187-194 Available from: http://www.sciencedirect. com/science/article/pii/S0273122399001018

Ready to submit your research? Choose BMC and benefit from:

- fast, convenient online submission

- thorough peer review by experienced researchers in your field

- rapid publication on acceptance

- support for research data, including large and complex data types

- gold Open Access which fosters wider collaboration and increased citations

- maximum visibility for your research: over $100 \mathrm{M}$ website views per year

At BMC, research is always in progress.

Learn more biomedcentral.com/submissions 